\title{
Tailoring Acidic Oxygen Reduction Selectivity on Single-Atom Catalysts via Modification of First and Second Coordination Spheres
}

Cheng Tang, ${ }^{1+}$ Ling Chen, ${ }^{1 \star}$ Haijing Li, ${ }^{2 \ddagger}$ Laiquan $\mathrm{Li},{ }^{1 \star}$ Yan Jiao, ${ }^{1}$ Yao Zheng, ${ }^{1}$ Haolan $\mathrm{Xu},{ }^{3}$ Kenneth Davey, ${ }^{1}$ Shi-Zhang Qiao ${ }^{1 *}$

${ }^{1}$ School of Chemical Engineering and Advanced Materials, The University of Adelaide, SA 5005, Australia

${ }^{2}$ University of Chinese Academy of Sciences, Beijing 100049, People's Republic of China

${ }^{3}$ Future Industries Institute, University of South Australia, Adelaide, SA 5095, Australia 


\section{Supplementary Texts}

\section{Experimental Section}

Synthesis of CoNC. The CoNC sample was synthesized via conventional MOF-assisted pyrolysis. ${ }^{1} 0.30 \mathrm{~g}$ of $\mathrm{Co}\left(\mathrm{NO}_{3}\right)_{2} \cdot 6 \mathrm{H}_{2} \mathrm{O}$ and $5.58 \mathrm{~g}$ of $\mathrm{Zn}\left(\mathrm{NO}_{3}\right)_{2} \cdot 6 \mathrm{H}_{2} \mathrm{O}$ was dissolved in $200 \mathrm{~mL}$ of methanol (HPLC Grade) to form a clear solution that was injected into $200 \mathrm{~mL}$ of methanol containing $6.16 \mathrm{~g}$ of 2-methylimidazole under stirring for $8 \mathrm{~h}$ at room temperature (RT, $22{ }^{\circ} \mathrm{C}$ ). The precipitate was centrifuged and washed with ethanol several times and dried under vacuum at $70{ }^{\circ} \mathrm{C}$ overnight $(12 \mathrm{~h})$. The as-obtained powder was placed in a tube-furnace and heated to $850{ }^{\circ} \mathrm{C}$ for $1 \mathrm{~h}$ at a heating rate of $5{ }^{\circ} \mathrm{C} \mathrm{min}^{-1}$ under Ar, followed by natural cooling to RT. The collected product was purified by $1.0 \mathrm{M}$ hydrochloric acid at $80{ }^{\circ} \mathrm{C}$ for $18 \mathrm{~h}$ to remove any nanoparticles. Following washing, filtering, and freeze-drying, samples were obtained for characterization and evaluation.

Synthesis of CB-based samples. Other samples were prepared via adsorption-annealing using commercial carbon black (Vulcan XC-72R, Fuel Cell Store) as substrate. Two (2) g of carbon black was dispersed in $100 \mathrm{~mL}$ of $9 \mathrm{M}$ nitric acid solution and refluxed at $90{ }^{\circ} \mathrm{C}$ for $10 \mathrm{~h}$, followed by washing, filtering, and freeze-drying. One (1) g of the as-obtained oxidized carbon black was dispersed in $400 \mathrm{~mL}$ of Millipore-filtered water by tip-sonication for $60 \mathrm{~min}$ to prepare a homogeneous dispersion. Subsequently, $60 \mathrm{~mL}$ of $\mathrm{Co}\left(\mathrm{NO}_{3}\right)_{2}$ aqueous solution $\left(3 \mathrm{mg} \mathrm{mL}^{-1}\right)$ was added dropwise into carbon black dispersion under vigorous stirring for $12 \mathrm{~h}$. The $\mathrm{Co}^{2+}$-adsorbed $\mathrm{CB}$ was collected via washing, centrifugation, and freeze-drying. The as-obtained powder was placed in a tube furnace and then heated to $900{ }^{\circ} \mathrm{C}$ for $1 \mathrm{~h}$ at a heating rate of $5{ }^{\circ} \mathrm{C} \mathrm{min}{ }^{-1}$ under controlled atmosphere, Ar for CoOC and $\mathrm{Ar} / \mathrm{NH}_{3}$ for CoNOC, followed by natural cooling to RT. The samples were obtained after acid treatment, washing, filtering, and freeze-drying, as for that for CoNC. Metal-free nitrogen-doped carbon black (NC) and oxygen-doped carbon black (OC) were synthesized by annealing the oxidized carbon black in, respectively, $\mathrm{Ar} / \mathrm{NH}_{3}$ and $\mathrm{Ar}$.

Materials Characterization. The morphology of the samples was characterized using FEI Quanta 600 SEM operated at $20.0 \mathrm{kV}$ and FEI Titan Themis 80-200 operated at $200.0 \mathrm{kV}$. XPS analysis was carried out on a Kratos Axis Ultra using a monochromatic Al Ka source. Co content was determined by an inductively-coupled plasma mass-spectrometer (Agilent 8900x QQQ-ICP-MS, Agilent, USA). C and O K-edge X-ray absorption spectra were collected on the soft X-ray 
beamline at Australian Synchrotron, Clayton, Victoria. Co K-edge X-ray absorption spectra were acquired at 1W1B station in Beijing Synchrotron Radiation Facility (BSRF, operated at $2.5 \mathrm{GeV}$ with a maximum current of $250 \mathrm{~mA}$ ). The Co SACs were measured at RT in fluorescence excitation mode using an Ar-filled Lytle-type detector. Co-foil, $\mathrm{CoO}$, and $\mathrm{CoPc}$ were used as reference samples, and measured in a transmission mode using standard $\mathrm{N}_{2}$-filled ion chambers. The EXAFS raw data were background-subtracted, normalized, and Fourier transformed by standard procedures using ATHENA module implemented in the IFEFFIT software package. ${ }^{2-3}$ Least-squares curve fitting analyses of the EXAFS $\chi(k)$ data was carried out using the ARTEMIS program. ${ }^{3}$

Electrochemical Measurements. All electrochemical tests were performed with a three-electrode system controlled by a CHI 760E electrochemistry station ( $\mathrm{CH}$ Instrument, USA). A RRDE loaded with catalysts, a $\mathrm{RuO}_{2}$-coated titanium-mesh and an $\mathrm{Ag} / \mathrm{AgCl}$ (saturated $\mathrm{KCl}$ ) were used, respectively, as working electrode, counter electrode and reference electrode. The RRDE assembly (AFE7R9GCPT, Pine Research Instrumentation, USA) consisted of a glassy-carbon rotation disk electrode (disk area $0.2475 \mathrm{~cm}^{2}$ ) and a Pt-ring (ring area $0.1866 \mathrm{~cm}^{2}$ ), with a theoretical collection efficiency $\left(N_{\mathrm{C}}\right)$ of $37 \%$. The catalyst ink was prepared by dispersing $5.0 \mathrm{mg}$ of electrocatalyst and $1.2 \mathrm{mg}$ of acetylene black in $950 \mu \mathrm{L}$ of ethanol and $50 \mu \mathrm{L}$ of Nafion solution ( $5.0 \mathrm{wt} \%$ ), followed by sonication for $30 \mathrm{~min}$. $5.0 \mu \mathrm{L}$ of the as-obtained suspension was pipetted onto the disk electrode, naturally dried prior to use.

Electrochemical measurements were carried out in $\mathrm{O}_{2}$-saturated $0.10 \mathrm{M} \mathrm{HClO}_{4}$ aqueous solution at RT. The rotating speed of the working electrode was $1600 \mathrm{rpm}$ throughout the tests. The ring-electrode was set at a constant potential of $1.20 \mathrm{~V}$ vs RHE to detect the generated $\mathrm{H}_{2} \mathrm{O}_{2}$. Linear sweep voltammetry (LSV) measurements were conducted at a scan rate of $5.0 \mathrm{mV} \mathrm{s}^{-1}$.

The selectivity of hydrogen peroxide $\left(\mathrm{H}_{2} \mathrm{O}_{2} \%\right)$ and electron transfer number $(n)$ were calculated based on the disk current $\left(I_{\mathrm{d}}\right)$ and ring current $\left(I_{\mathrm{r}}\right)$ from:

$$
\begin{aligned}
& \mathrm{H}_{2} \mathrm{O}_{2} \%=200 \times\left(I_{\mathrm{r}} / N_{\mathrm{C}}\right) /\left(\left|I_{\mathrm{d}}\right|+I_{\mathrm{r}} / N_{\mathrm{C}}\right) \\
& n=4 \times\left|I_{\mathrm{d}}\right| /\left(\left|I_{\mathrm{d}}\right|+I_{\mathrm{r}} / N_{\mathrm{C}}\right)
\end{aligned}
$$

Tafel slopes were calculated from the Tafel equation:

$$
\eta=b \log \left(j / j_{0}\right)
$$

where $\eta$ is overpotential, $b$ is Tafel slope, $j$ is current density, and; $j_{0}$ is exchange current density. 
Bulk electrolysis. Bulk electrosynthesis of $\mathrm{H}_{2} \mathrm{O}_{2}$ in $0.10 \mathrm{M} \mathrm{HClO}_{4}$ was carried out in a customized H-cell electrolyzer. A carbon-paper electrode $\left(1.5 \times 1.5 \mathrm{~cm}^{2}\right)$ coated with CoNOC $\left(0.2 \mathrm{mg} \mathrm{cm}^{-2}\right)$ by air brushing was used as the working electrode. A Ti-mesh electrode coated with $\mathrm{RuO}_{2}$ and $\mathrm{Ag} / \mathrm{AgCl}$ (saturated $\mathrm{KCl}$ ) were used, respectively, as counter electrode and reference electrode. A Nafion 117 membrane (Fuel Cell Store) was used to separate chambers.

$\mathrm{H}_{2} \mathrm{O}_{2}$ concentration was quantitatively determined by $\mathrm{Ce}^{4+}$ titration $\left(2 \mathrm{Ce}^{4+}+\mathrm{H}_{2} \mathrm{O}_{2} \rightarrow 2 \mathrm{Ce}^{3+}+\right.$ $\left.2 \mathrm{H}^{+}+\mathrm{O}_{2}\right),{ }^{4}$ in which the $\mathrm{Ce}^{4+}$ solution is yellow whilst the $\mathrm{Ce}^{3+}$ solution is colorless. The $\mathrm{H}_{2} \mathrm{O}_{2}$ concentration-absorbance curve was plotted by linearly fitting the absorbance values at a wavelength length of $320 \mathrm{~nm}$ for known concentrations of $0,0.01,0.02,0.05,0.1,0.2,0.3,0.4$, and $0.5 \mathrm{mM}$ of $\mathrm{Ce}^{4+}$. The obtained sample solutions were mixed with $0.5 \mathrm{mM} \mathrm{Ce} \mathrm{C}^{4+}$ solution by specific dilution, and the absorbance at $320 \mathrm{~nm}$ was measured after standing for $2 \mathrm{~h}$ to determine $\mathrm{Ce}^{4+}$ concentration.

The yield of $\mathrm{H}_{2} \mathrm{O}_{2}$ was determined based on reduced $\mathrm{Ce}^{4+}$ concentration. The Faradaic efficiency ( $\mathrm{FE}$ ) for $\mathrm{H}_{2} \mathrm{O}_{2}$ generation in $\mathrm{H}$-cell was computed as follows:

$\mathrm{FE}(\%)=\left(\right.$ mole of generated $\left.\mathrm{H}_{2} \mathrm{O}_{2} \times 2 \times 96,485\right) /($ total consumed charge $) \times 100 \%$

In situ ATR-SEIRAS. In situ ATR-SEIRAS was performed on a Nicolet iS20 spectrometer equipped with a VeeMax III (PIKE technologies) accessory. The electrochemical test was conducted in a custom-made three-electrode electrochemical single cell. A Pt wire and a saturated $\mathrm{Ag} / \mathrm{AgCl}$ were used as the counter and reference electrodes, respectively. A Si wafer coated with $\mathrm{Au}$ thin layer was used to load catalysts and served as the working electrode. ${ }^{5}$ The in situ ATRSEIRAS spectra were recorded by varying the potential stepwise from $0.8 \mathrm{~V}$ to $0 \mathrm{~V}$ vs $\mathrm{RHE}$ in $\mathrm{O}_{2}$-saturated $0.10 \mathrm{M} \mathrm{HClO}_{4} .70$ scans were collected with a spectral resolution of $4 \mathrm{~cm}^{-1}$ for each spectrum. The spectrum recorded at the initial potential of $0.9 \mathrm{~V}$ was used for the background subtraction.

\section{Computation Models and Methods}

Twelve (12) models were built to represent Co-SACs with varied configurations at the molecular level. These models are shown in Figure S2, with uniform lattice constant of $12.3 \AA \times 12.3 \AA \times 15$ $\AA$. The vertical separation between periodically repeated images was set to be at least $15 \AA$ in all cases, to ensure no interaction between images. The base layers and adsorbates were allowed to fully relax in all configurations. The implicit solvent effect was considered by using VASPsol, which implicitly involves counter charges in the system through solving the linearized Poisson- 
Boltmzann. ${ }^{6}$ Within this model, the solvent dielectric constant was set to be 78.4 , width of dielectric cavity $0.6 \AA$, cutoff charge density 0.0025 , and the effective cavity surface tension 0.000525 .

All DFT calculations were performed with the Vienna Ab Initio Simulation Package (VASP) code. $^{7}$ The Perdew-Burke-Ernzerhof (PBE) was employed for electron exchange-correlation. ${ }^{8}$ Projector Augmented Wave (PAW) potentials were used to describe the ionic cores. ${ }^{9}$ The atomic relaxations were carried out with the quasi-Newton minimization scheme until the maximum force on any atom was below $0.02 \mathrm{eV} \AA^{-1}$. The geometry optimizations were performed with a planewave cutoff of $400 \mathrm{eV}$. The Brillouin zones of all systems were performed with Monhorst-Pack grids. ${ }^{10}$ The k-points were set to be $2 \times 2 \times 1$ with Gamma centered grids for all structures for geometry optimization and $20 \times 20 \times 1$ for accurate density of state (DOS) computation. The Fermi level was smeared with the Methfessel-Paxton approach. Dipole corrections were included in all the calculations to minimize the inaccuracies in the total energy due to the simulated slab interactions. The dipole moment was calculated parallel to the z-direction.

The free energies of adsorbed species, computed based on computational hydrogen electrode (CHE) model, ${ }^{11}$ are defined as:

$$
G=E+Z P E-T S
$$

where $E$ is the DFT-derived total ground state energy of a system. $Z P E$ is the zero-point energy correction and TS is the entropy correction computed with standard methods ${ }^{11-12}$ and used to convert $E$ into free energy $(G)$ at $300 \mathrm{~K}$. The free energies of $\mathrm{O}_{2}, \mathrm{H}_{2} \mathrm{O}_{2}, \mathrm{H}_{2}$ and $\mathrm{H}_{2} \mathrm{O}$ were computed by traditional process, ${ }^{13}$ and values used are given in Table $\mathrm{S} 1$.

Kinetic barriers were computed using climbing-image nudged elastic band (CI-NEB). ${ }^{14} \mathrm{Six}(6)$ images were interpolated between the initial (IS) and the final state (FS) to determine minimum energy path (MEP), and geometry of the transition state (TS). The total energy and force thresholds for geometry optimizations were $1 \times 10^{-4} \mathrm{eV}$ and $0.05 \mathrm{eV} \AA^{-1}$, respectively. TSs were confirmed through frequency analysis to ensure only one imaginary frequency existed, assigned to MEP's unstable mode. 


\section{Supplementary Figures}
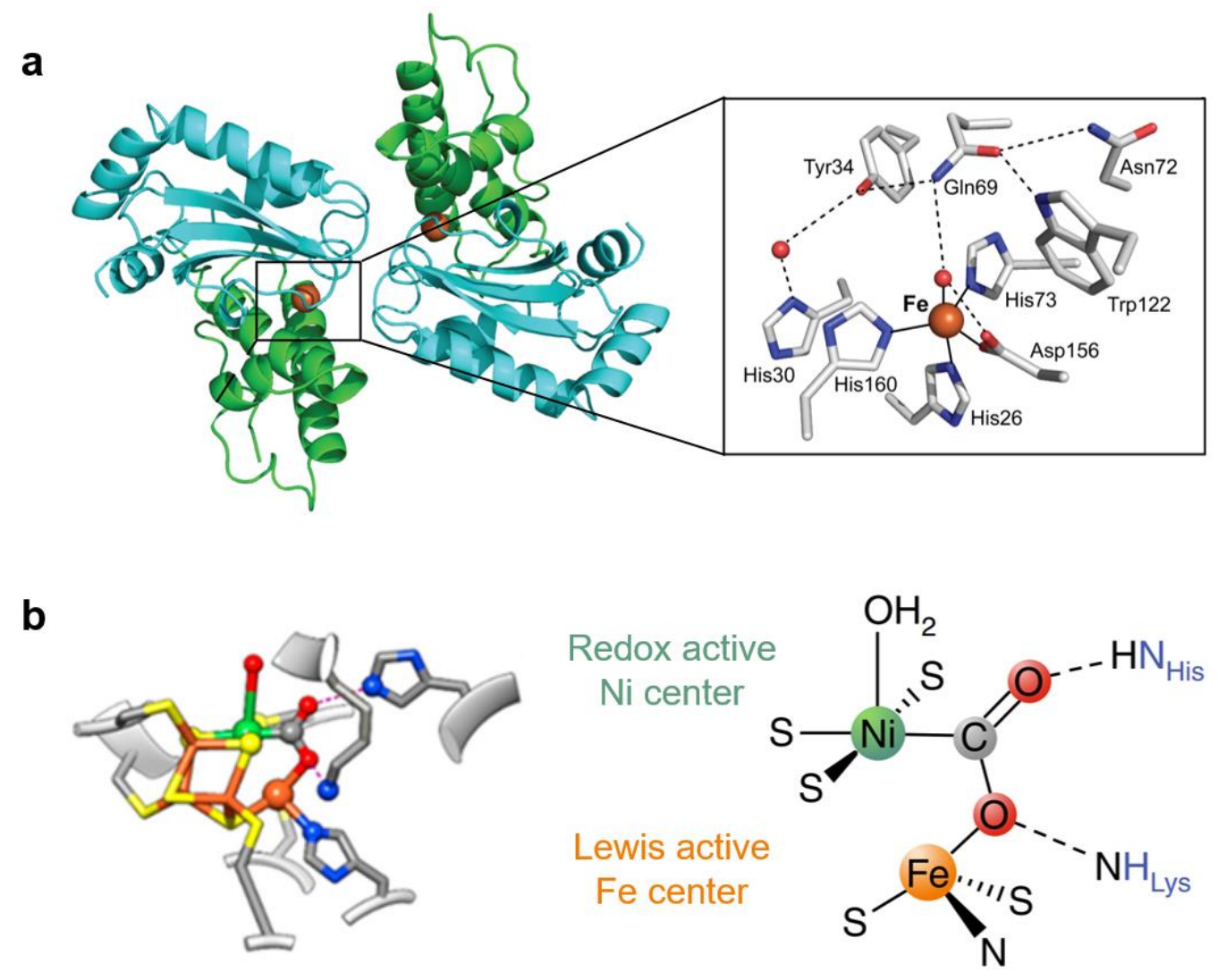

Figure S1. Schematic of metalloenzyme active sites with first and second coordination spheres. (a) E. coli Fe-superoxide dismutase. ${ }^{15}$ (b) NiFe-carbon monoxide dehydrogenases. ${ }^{16}$ 


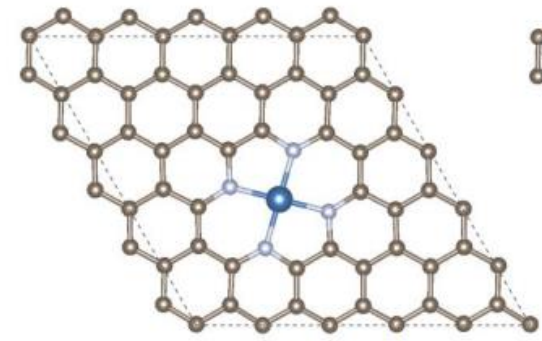

(1) $\mathrm{CoN}_{4}$

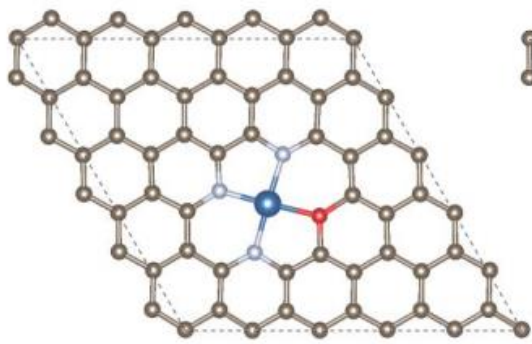

(4) $\mathrm{CoN}_{3} \mathrm{O}$

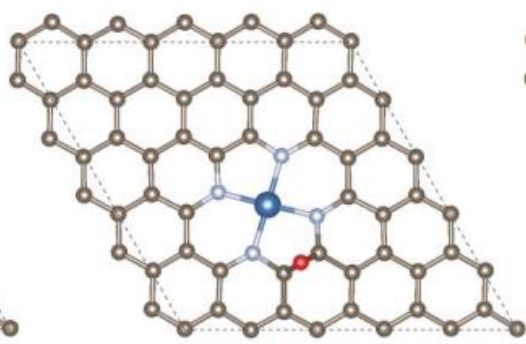

(2) $\mathrm{CoN}_{4}(\mathrm{O})$

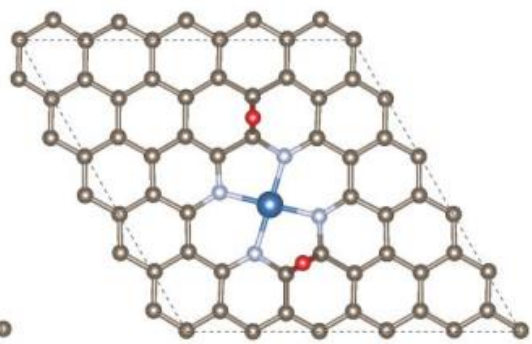

(3) $\mathrm{CoN}_{4}(2 \mathrm{O})$

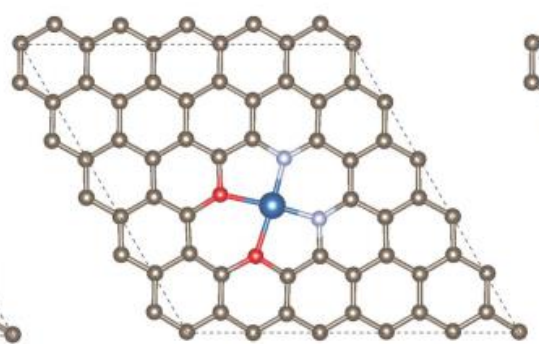

(5) $\mathrm{CoN}_{2} \mathrm{O}_{2}$

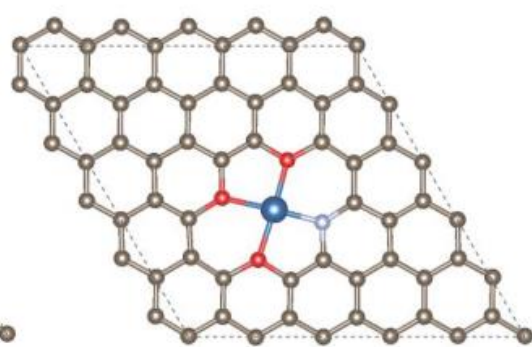

(6) $\mathrm{CoNO}_{3}$

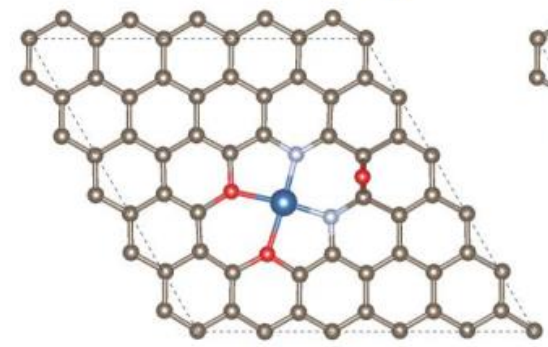

(7) $\mathrm{CoN}_{2} \mathrm{O}_{2}(\mathrm{O})$

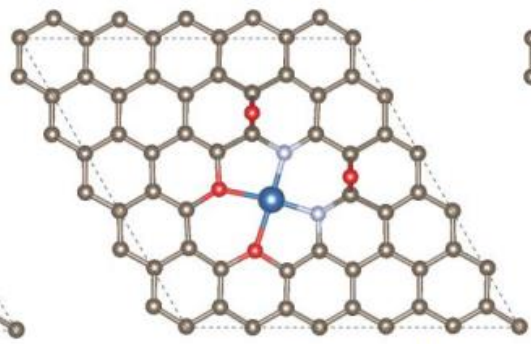

(8) $\mathrm{CoN}_{2} \mathrm{O}_{2}(2 \mathrm{O})$

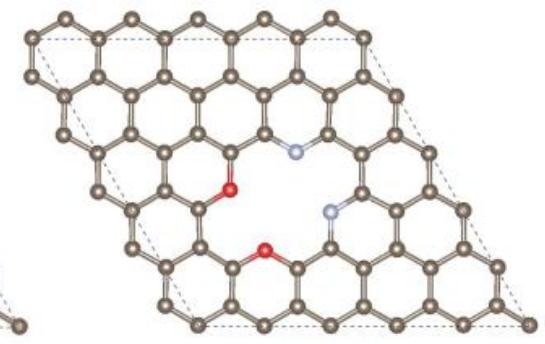

(9) $\mathrm{N}_{2} \mathrm{O}_{2}$

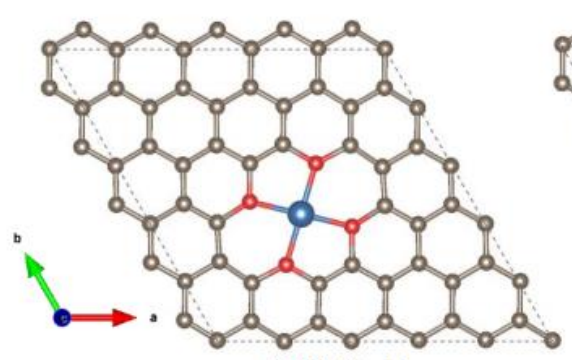

(10) $\mathrm{CoO}_{4}$

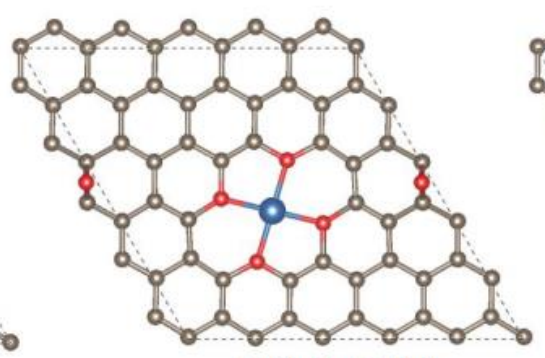

(11) $\mathrm{CoO}_{4}(\mathrm{O})$

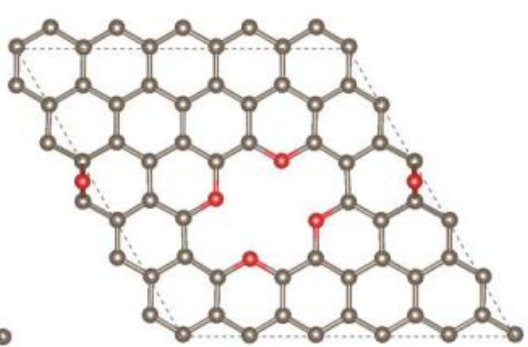

(12) $\mathrm{O}_{4}(\mathrm{O})$

Figure S2. Optimized geometry structures and abbreviation of bare Co-SACs moieties selected to compute ORR activity and selectivity. The grey, red, light blue, blue, and pink colored balls represent, respectively, $\mathrm{C}, \mathrm{O}, \mathrm{N}, \mathrm{Co}$, and $\mathrm{H}$ atoms. This color-code applies to all figures. 

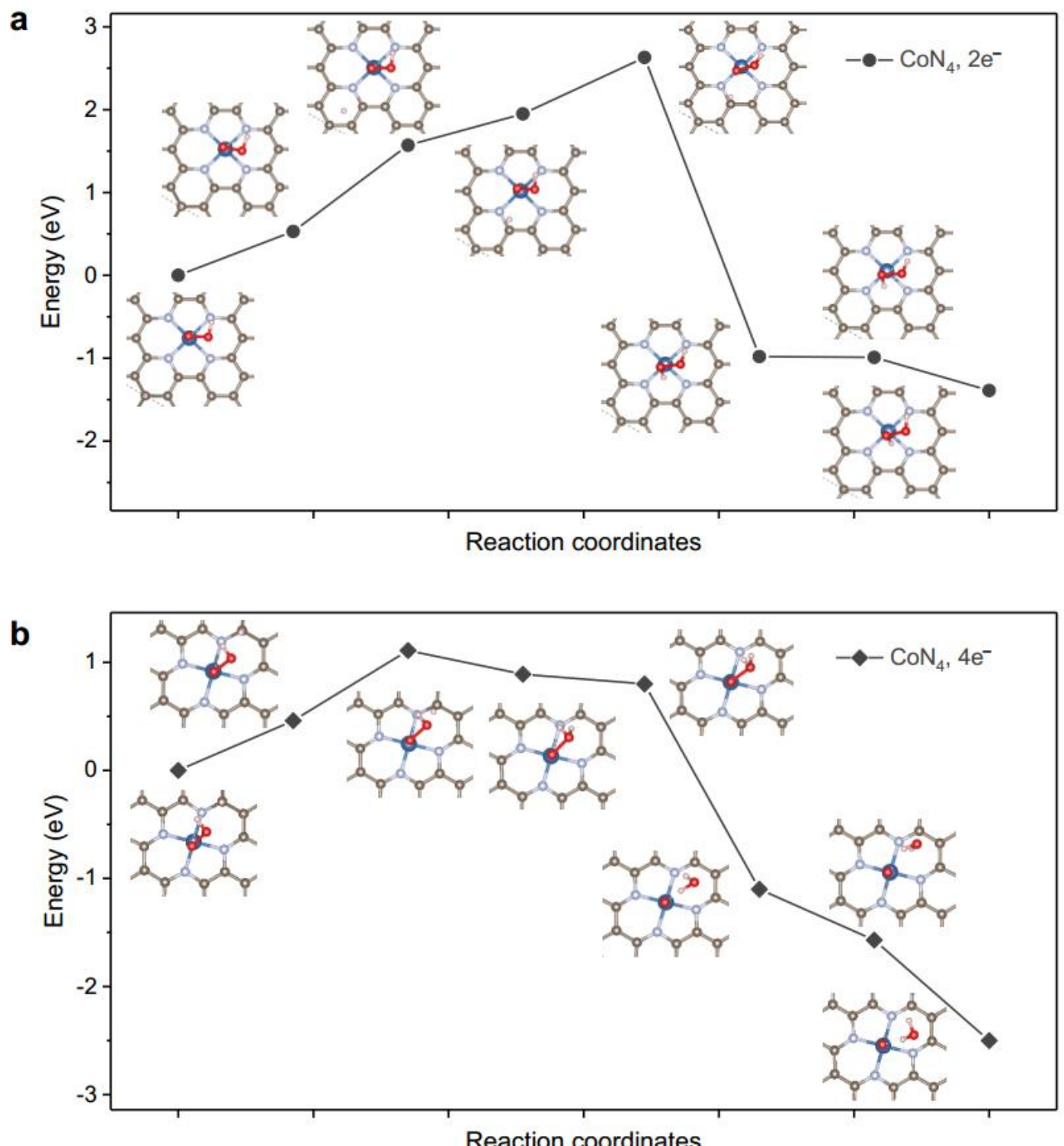

Figure S3. Minimum energy path (MEP) of $\mathrm{CoN}_{4}$ involved in (a) ${ }^{*} \mathrm{OOH}$ protonation for $2 \mathrm{e}^{-} \mathrm{ORR}$ pathway ( $* \mathrm{OOH}+\mathrm{H} \rightarrow \mathrm{H}_{2} \mathrm{O}_{2}$ ) and (b) $* \mathrm{OOH}$ dissociation for $4 \mathrm{e}^{-} \mathrm{ORR}$ pathway $(* \mathrm{OOH}+\mathrm{H} \rightarrow$ $* \mathrm{O}+\mathrm{H}_{2} \mathrm{O}$ ). Insets are optimized geometry structures of images on the pathway including initial, transition and final, states. 


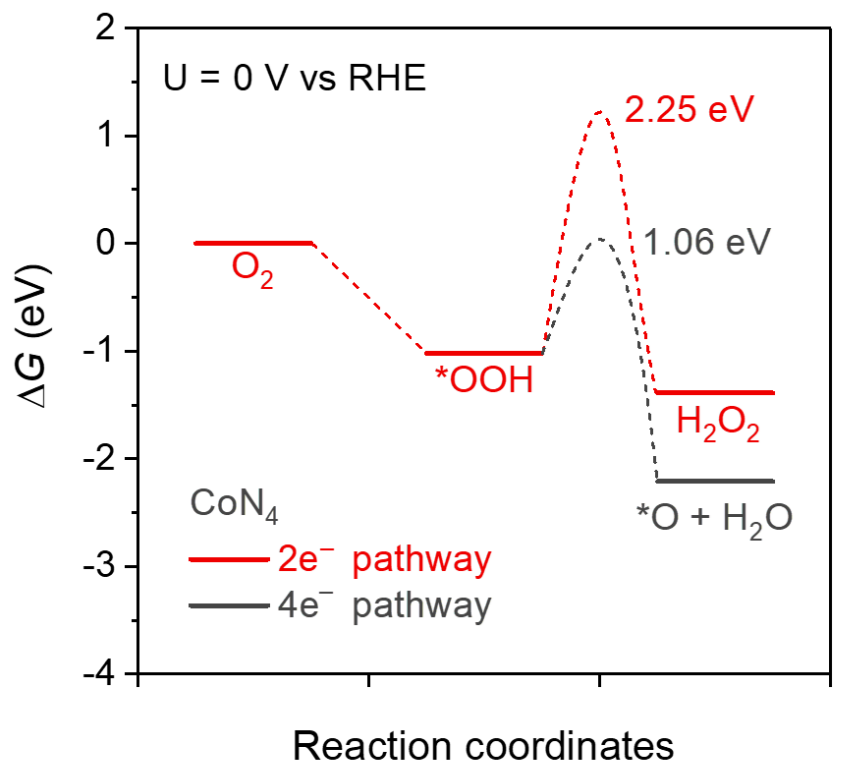

Figure S4. Free energy diagram for $2 \mathrm{e}^{-}$(red color) or $4 \mathrm{e}^{-}$(black) ORR pathway on $\mathrm{CoN}_{4}$ moiety. The kinetic barriers for ${ }^{*} \mathrm{OOH}$ to $\mathrm{H}_{2} \mathrm{O}_{2}$ or ${ }^{*} \mathrm{O}$ were computed by CI-NEB (details in Figure $\mathrm{S} 3$ ). 


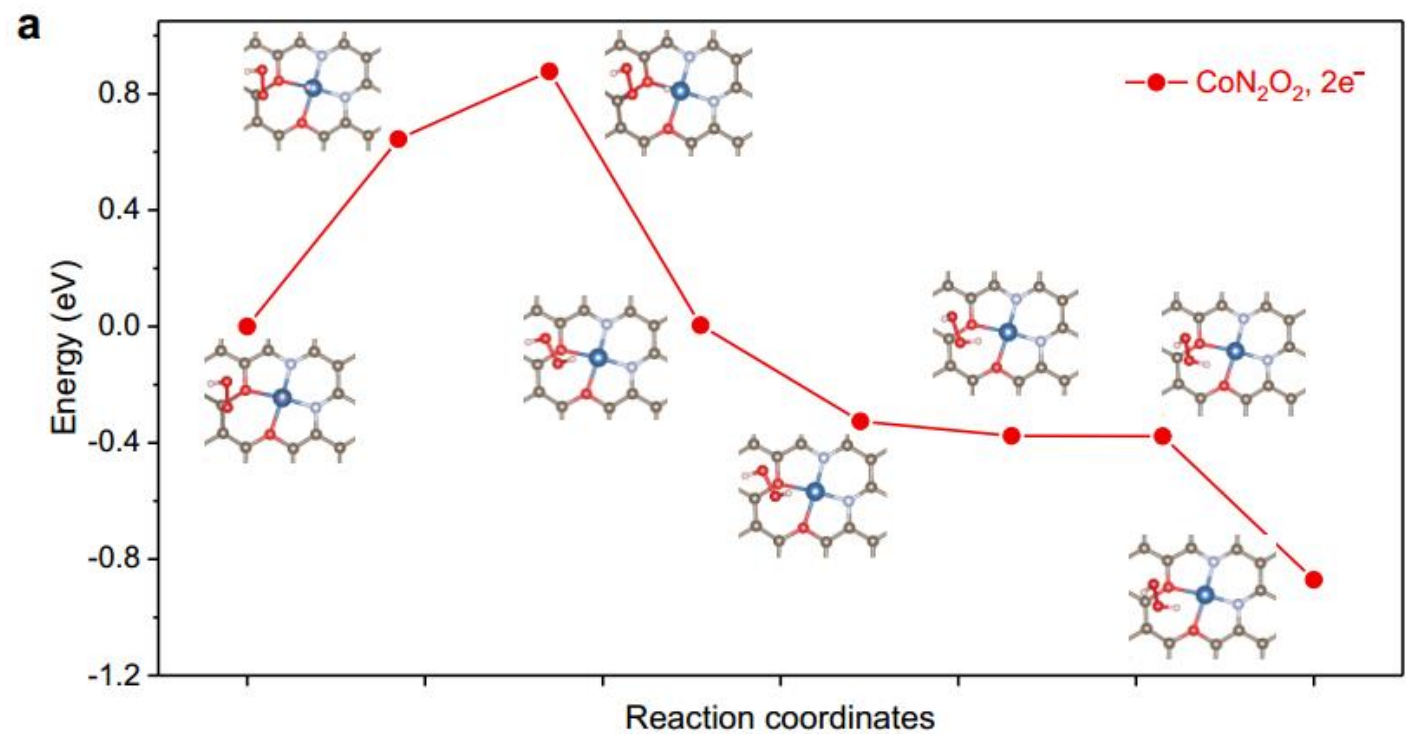

b

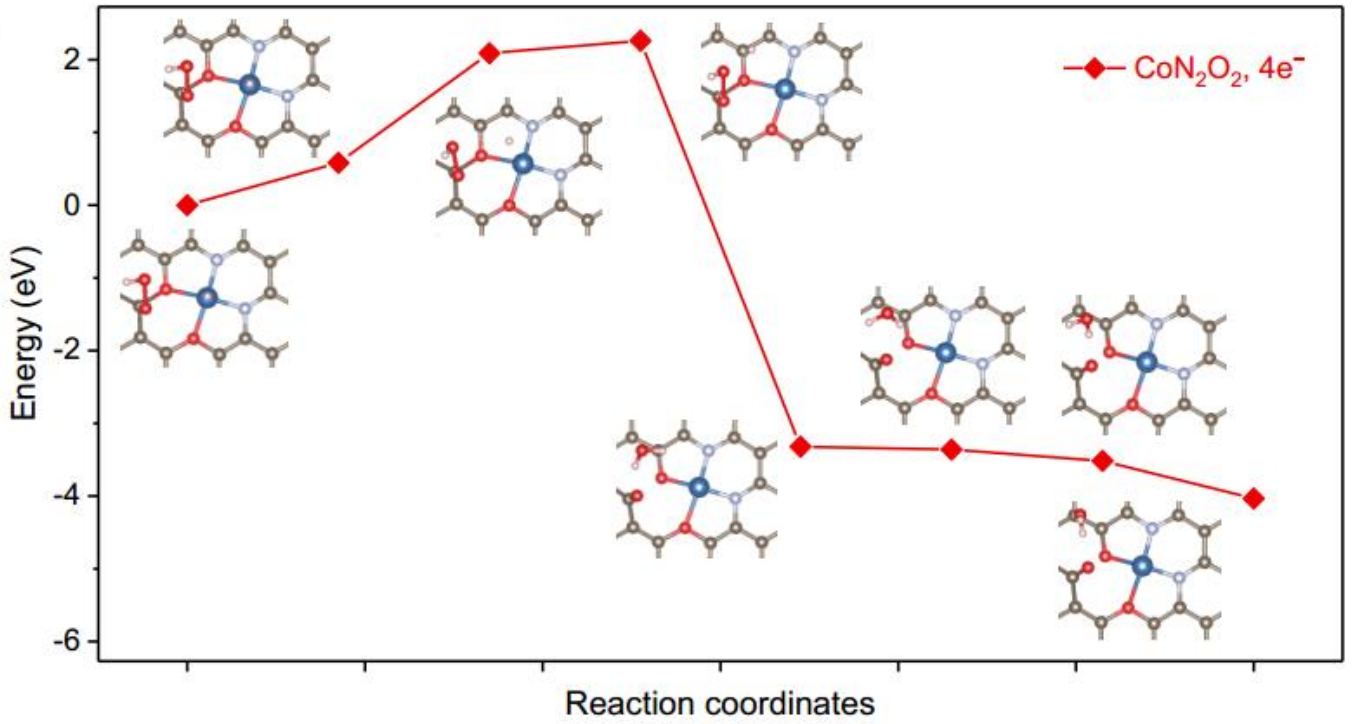

Figure S5. Minimum energy path (MEP) of $\mathrm{CoN}_{2} \mathrm{O}_{2}$ involved in (a) $* \mathrm{OOH}$ protonation for $2 \mathrm{e}^{-}$ ORR pathway ( ${ }^{*} \mathrm{OOH}+\mathrm{H} \rightarrow \mathrm{H}_{2} \mathrm{O}_{2}$ ) and (b) * $\mathrm{OOH}$ dissociation for $4 \mathrm{e}^{-} \mathrm{ORR}$ pathway $(* \mathrm{OOH}+$ $\mathrm{H} \rightarrow{ }^{*} \mathrm{O}+\mathrm{H}_{2} \mathrm{O}$ ). Insets are optimized geometry structures of the initial, transition and final, states. 

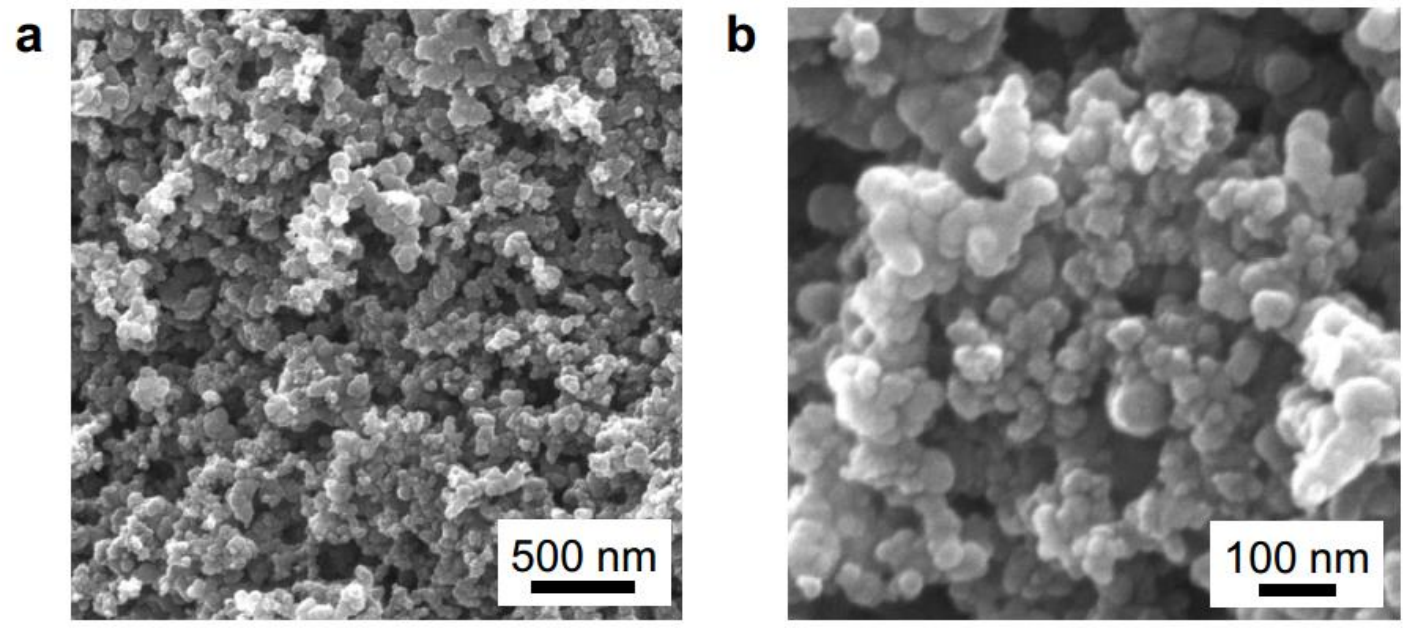

C

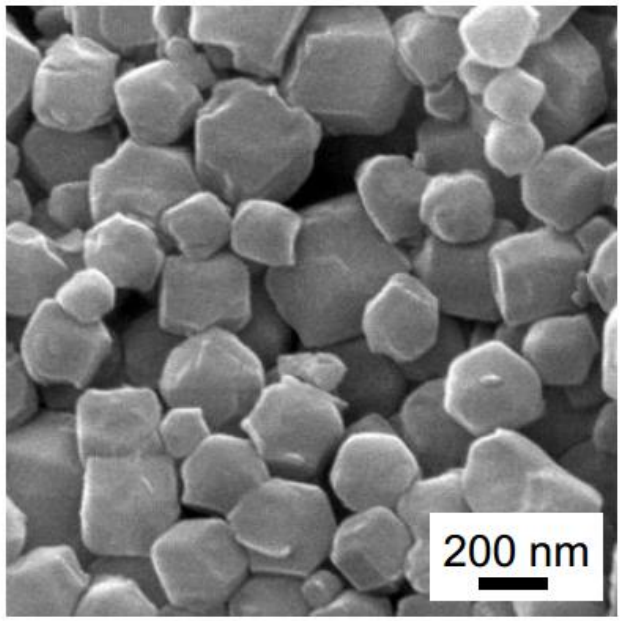

d

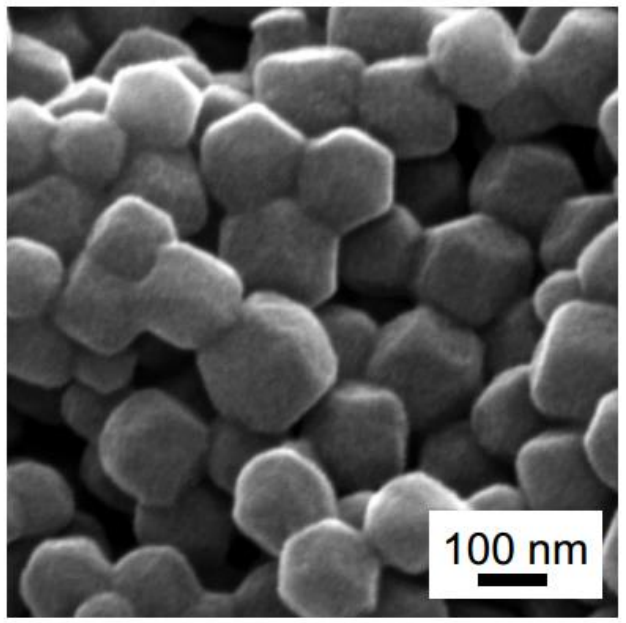

Figure S6. SEM images for (a, b) CoNOC, (c) MOF precursor of CoNC, and (d) CoNC. The morphology for CoNOC is the same as those for $\mathrm{CB}, \mathrm{CoOC}, \mathrm{NC}$, and $\mathrm{OC}$ samples. 


\section{$20 \mathrm{~nm}$}

Figure S7. Large-area HADDF-STEM image for CoNOC.
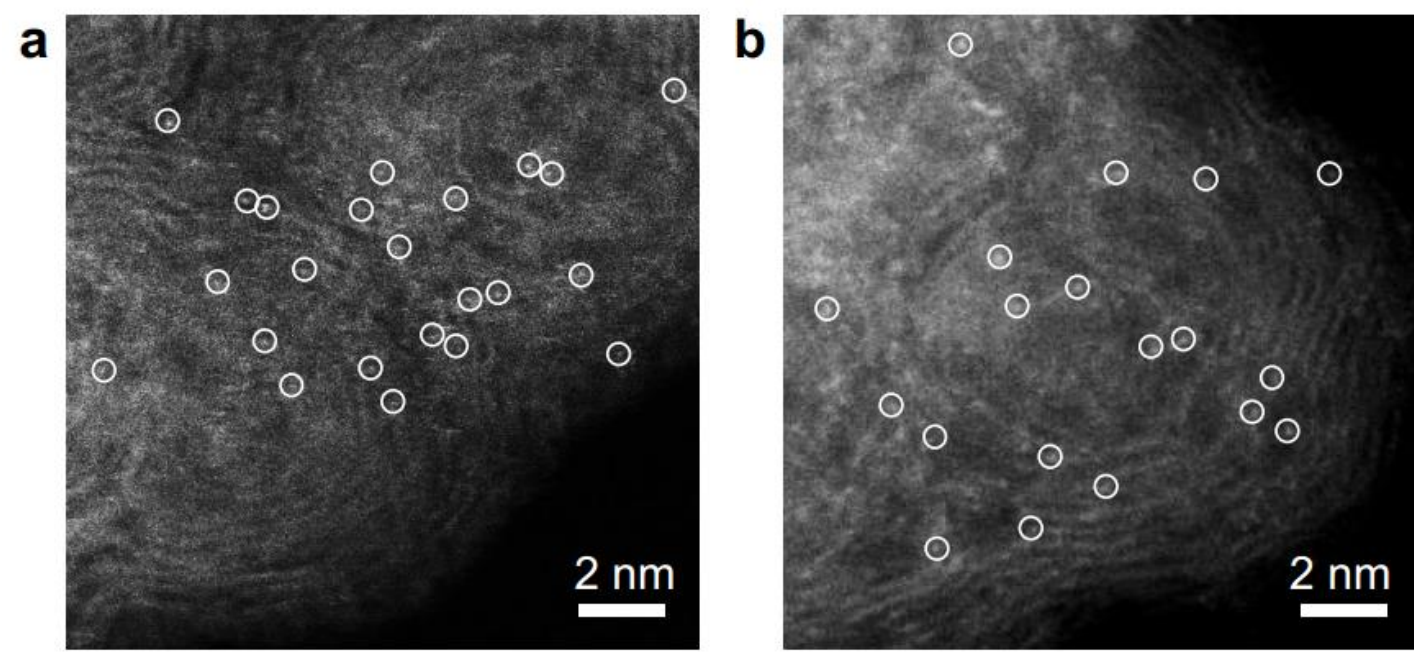

Figure S8. HADDF-STEM images for (a) CoNOC and (b) CoOC. Single Co atoms are highlighted by white circles. 

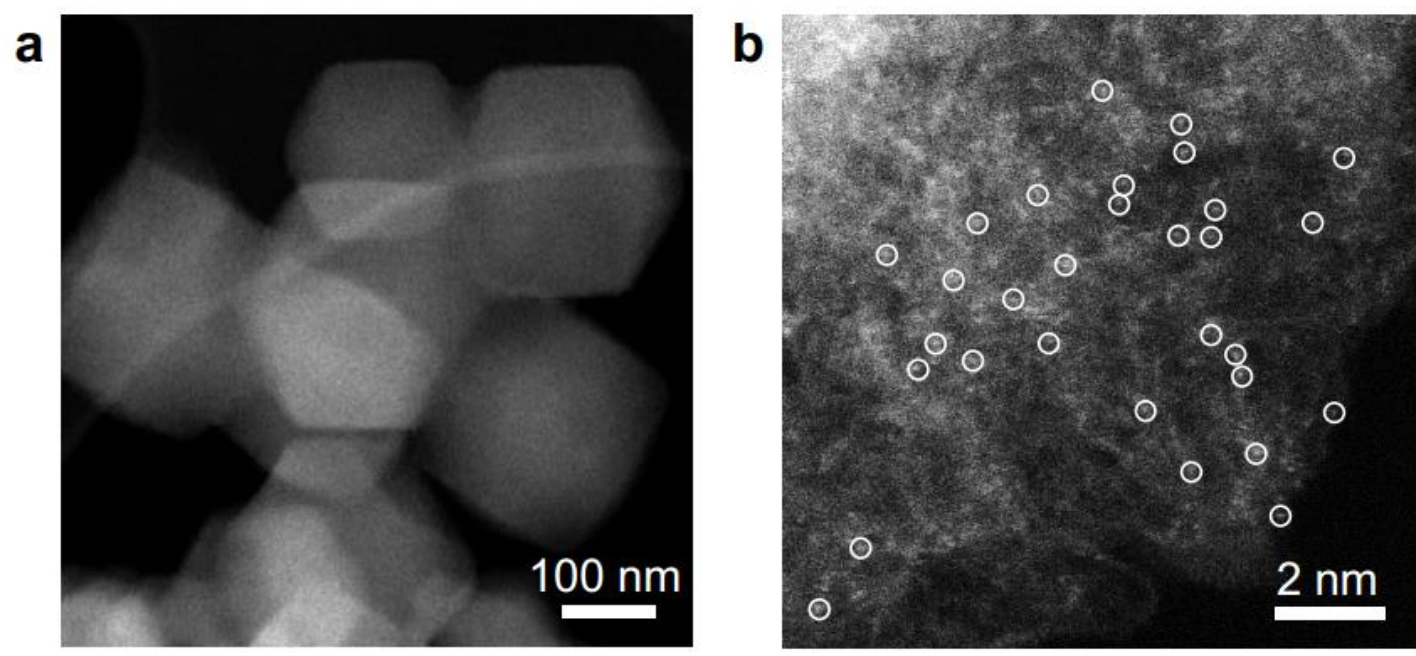

Figure S9. HADDF-STEM images for CoNC. Single Co atoms are highlighted by white circles.

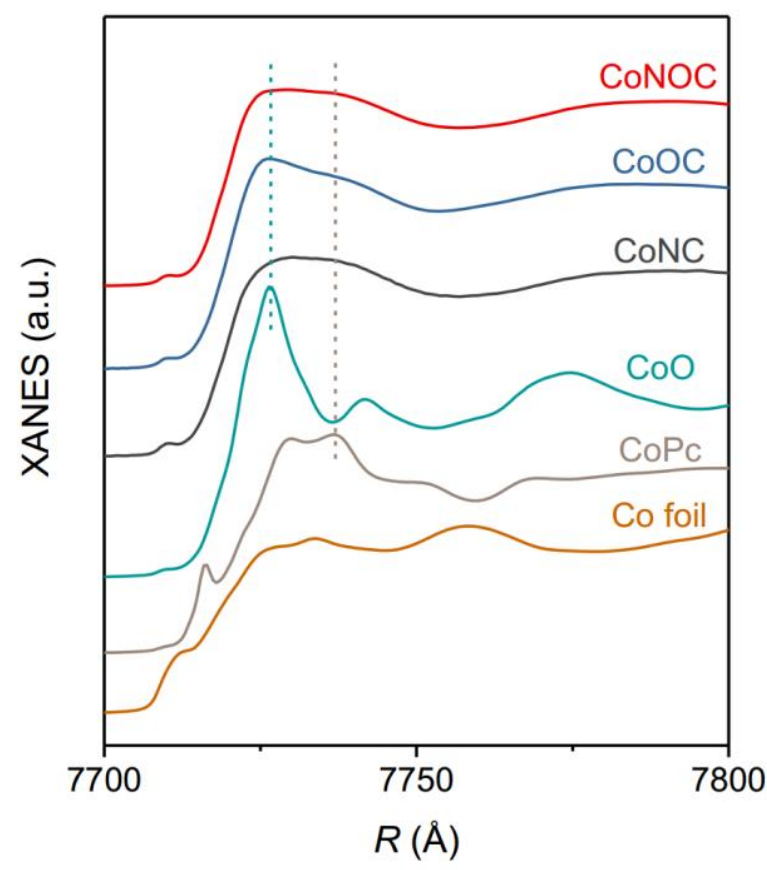

Figure S10. Co K-edge XANES spectroscopy for Co SACs and reference samples. 

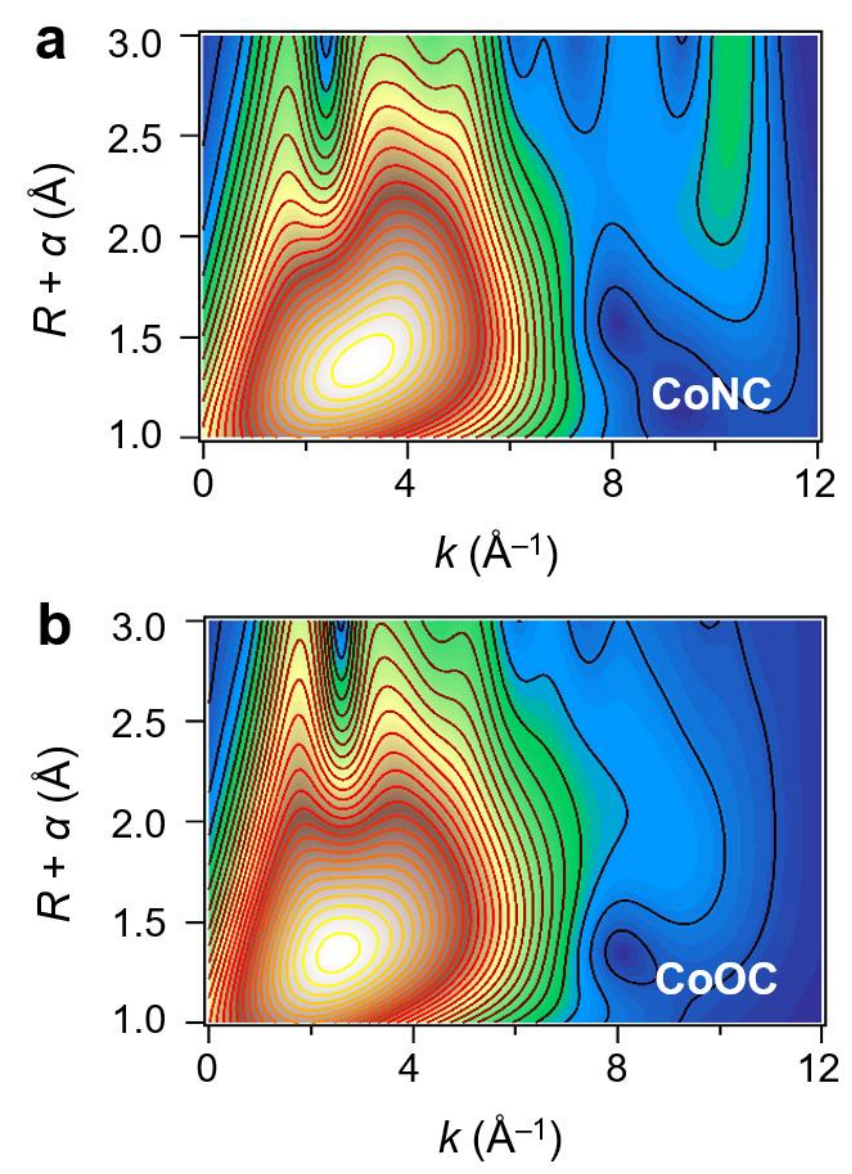

Figure S11. Co K-edge WT-EXAFS contour plots for CoNC and CoOC. 

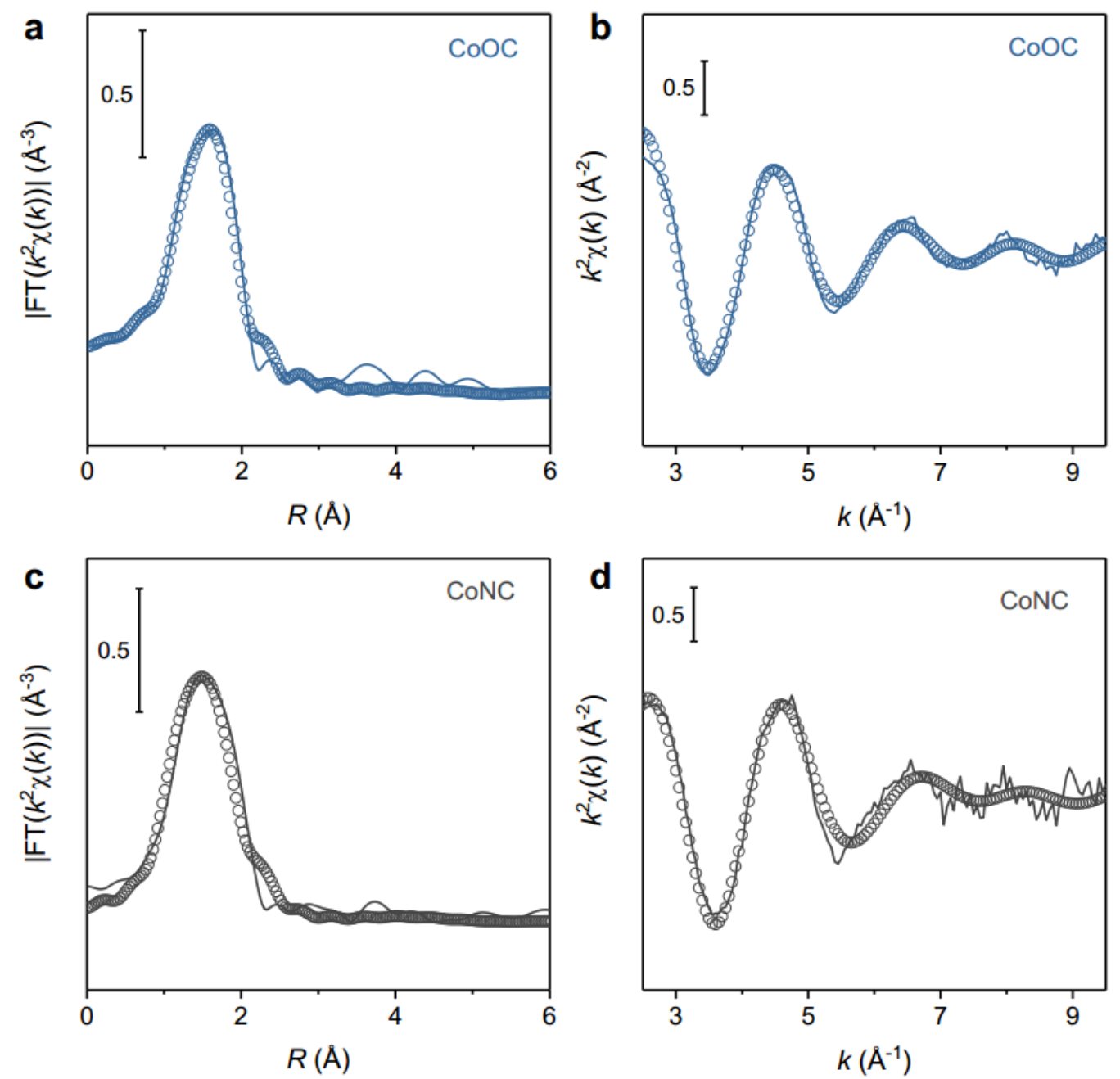

Figure S12. (a) Co K-edge EXAFS fitting analyses for CoOC in $R$ space and (b) $k$ space. (c) Co K-edge EXAFS fitting analysis of CoNC in $R$ space and (d) $k$ space. 


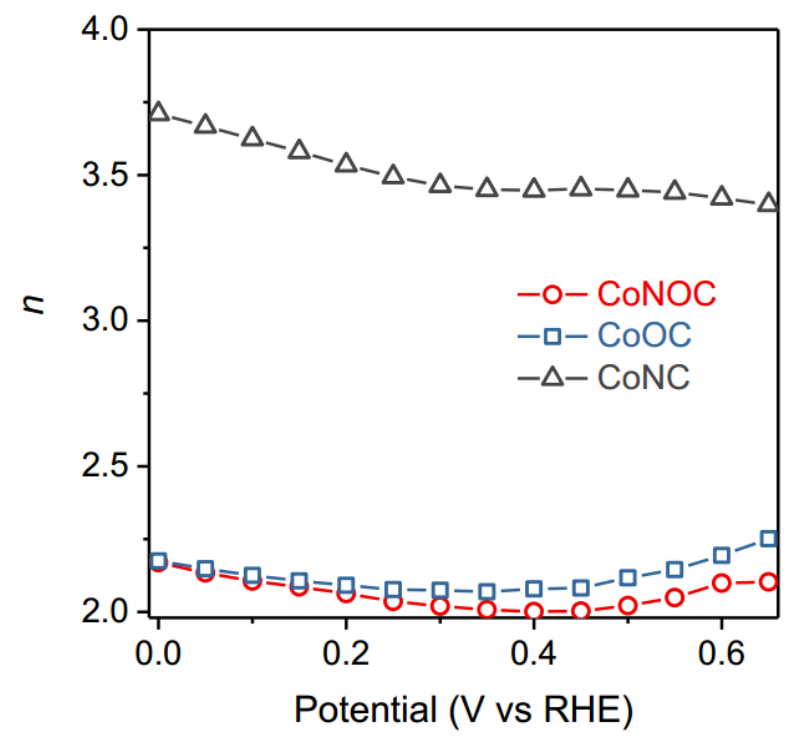

Figure S13. Calculated electron transfer number $(n)$ as a function of applied potential. 

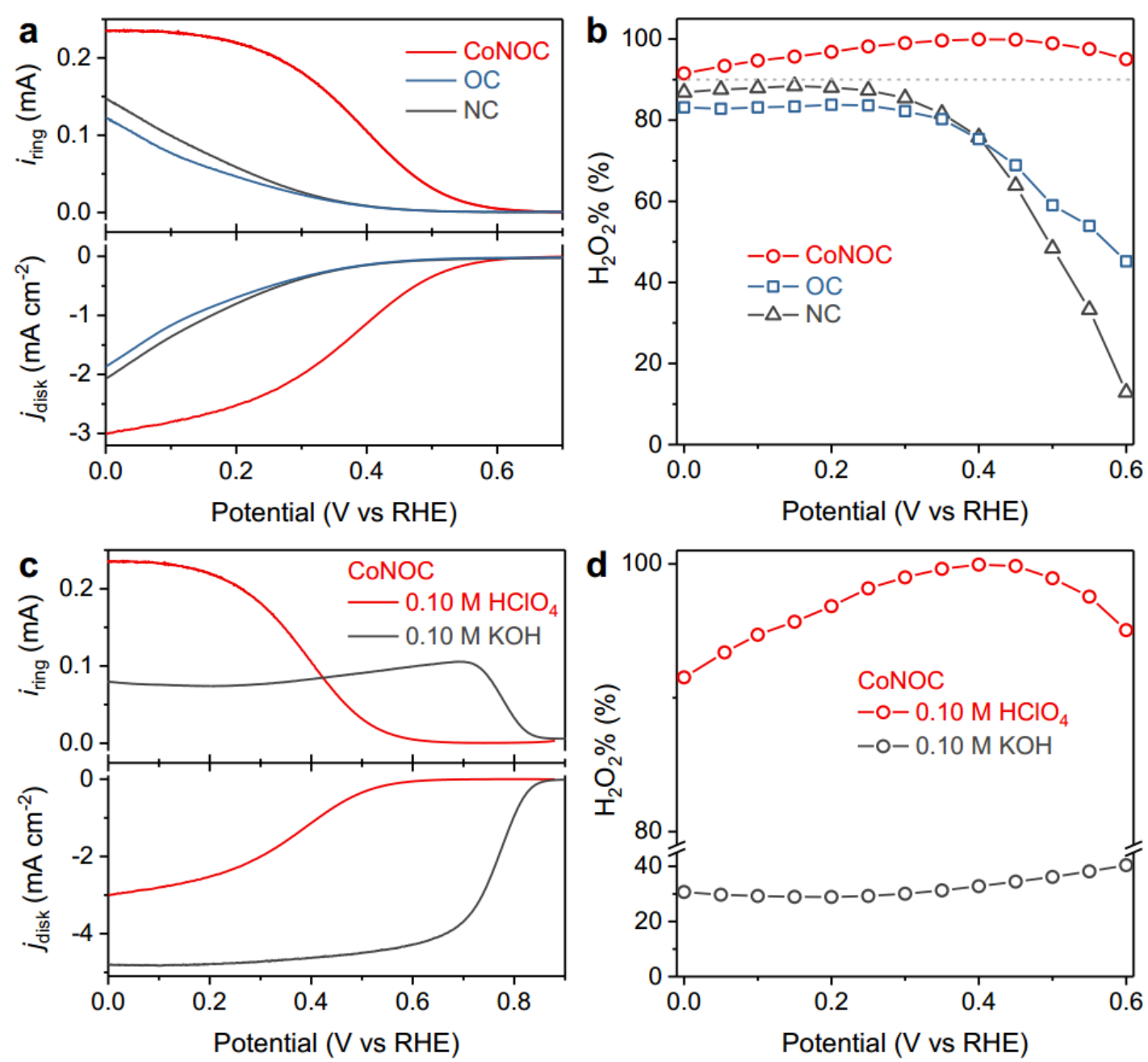

Figure S14. ORR performance for CoNOC compared with metal-free OC and NC samples. (a) LSV curves for ORR obtained in $\mathrm{O}_{2}$-saturated $0.10 \mathrm{M} \mathrm{HClO}_{4}$. (b) Calculated $\mathrm{H}_{2} \mathrm{O}_{2}$ selectivity as a function of applied potential. (c, d) ORR performance for CoNOC recorded in $\mathrm{O}_{2}$-saturated 0.10 $\mathrm{M} \mathrm{HClO}_{4}$ and $0.10 \mathrm{M} \mathrm{KOH}$. In alkaline condition, the CoNOC sample exhibits characteristics of $4 \mathrm{e}^{-}$ORR pathway. This is rationalized by the $\mathrm{pH}$-dependent interfacial solvation effect which impacts ORR selectivity. ${ }^{17}$ 

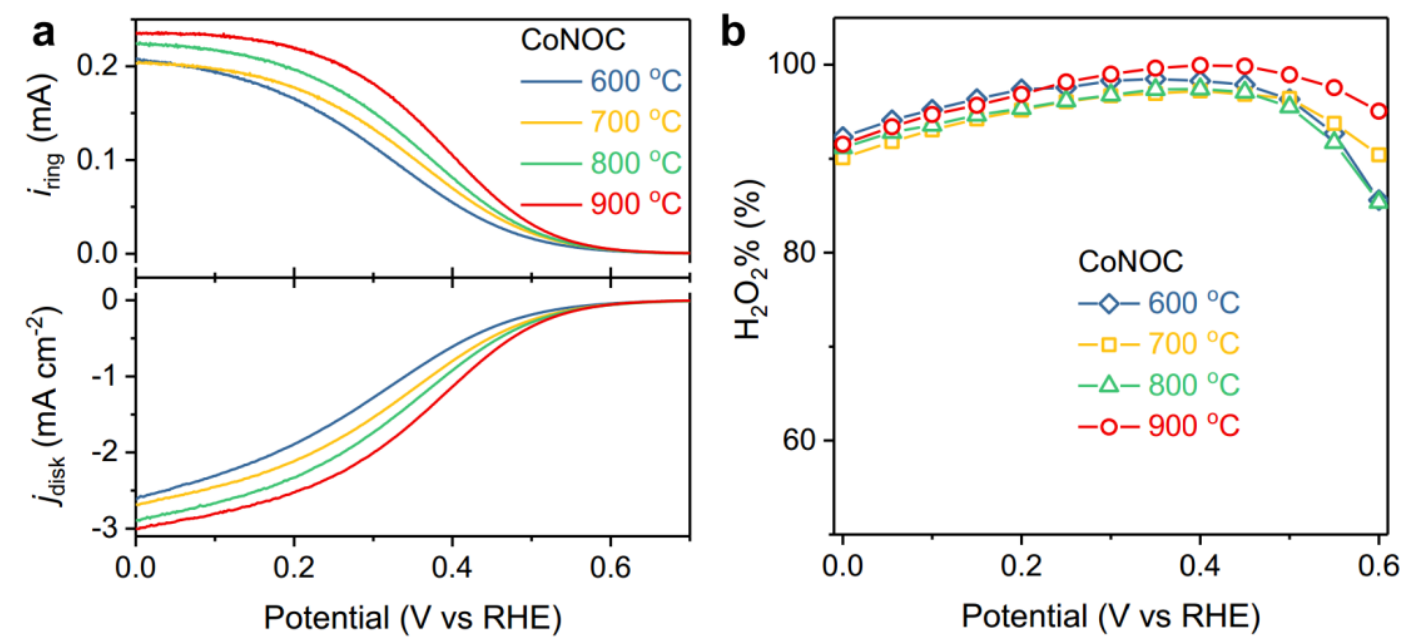

Figure S15. ORR performance for CoNOC samples prepared under annealing temperatures of 600, 700,800 and $900{ }^{\circ} \mathrm{C}$ and otherwise identical conditions. With increase of annealing temperature the ORR activity is gradually increased because of increased conductivity and degree of graphitization. Selectivity is almost unchanged because of the similar coordination structure. This finding therefore confirms that ORR activity and selectivity is dependent on the molecular-level structures of isolated Co atoms. 


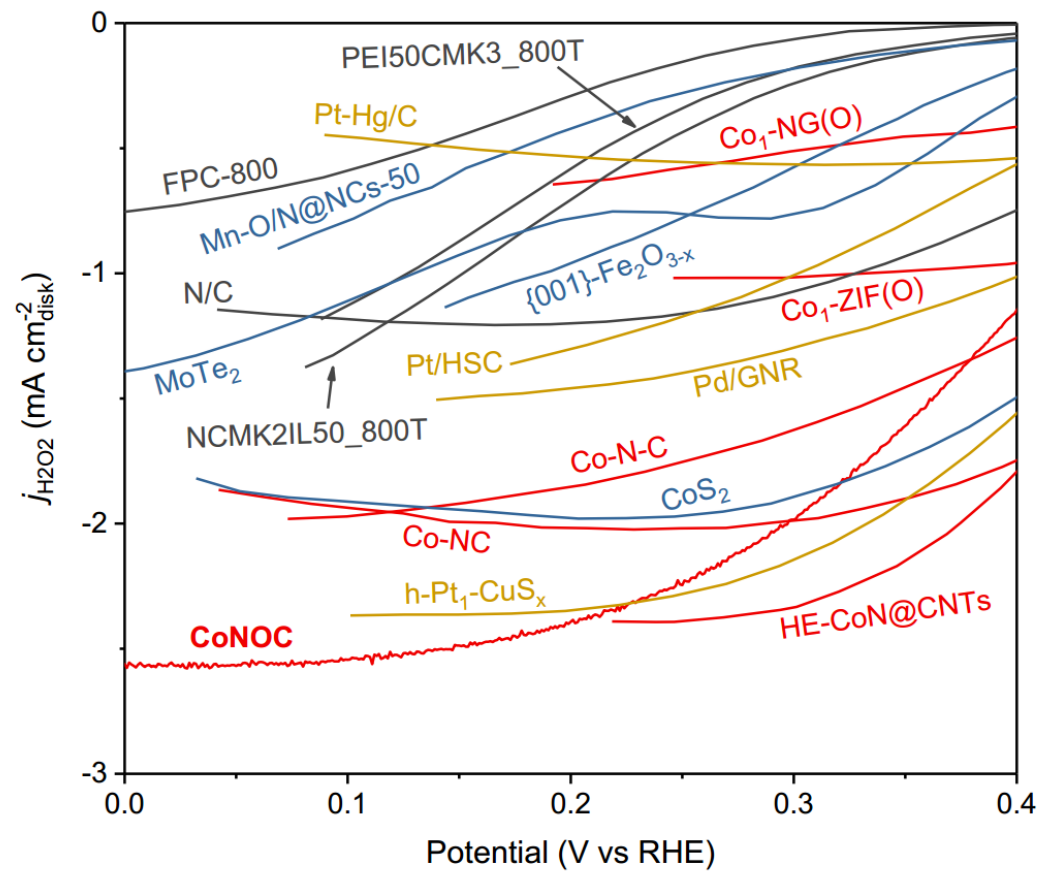

Figure S16. Comparison of performance of electrochemical $\mathrm{H}_{2} \mathrm{O}_{2}$ production via $2 \mathrm{e}^{-}$ORR in acidic media for CoNOC and reported catalysts (details in Table S4).
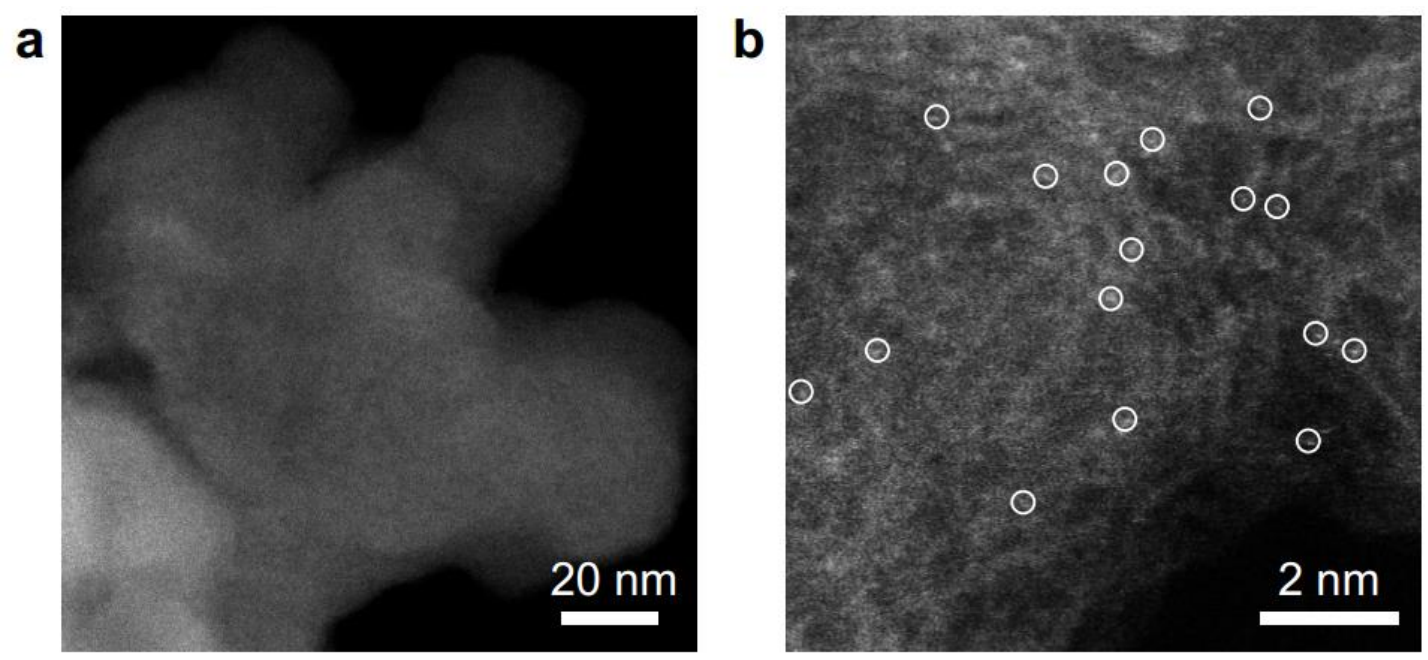

Figure S17. HADDF-STEM images for CoNOC following $11 \mathrm{~h}$ testing that show the stability of single Co atoms during long-term electrocatalysis. 


\section{$\mathrm{H}_{2} \mathrm{O}_{2}$ strip tests with different dilutions}
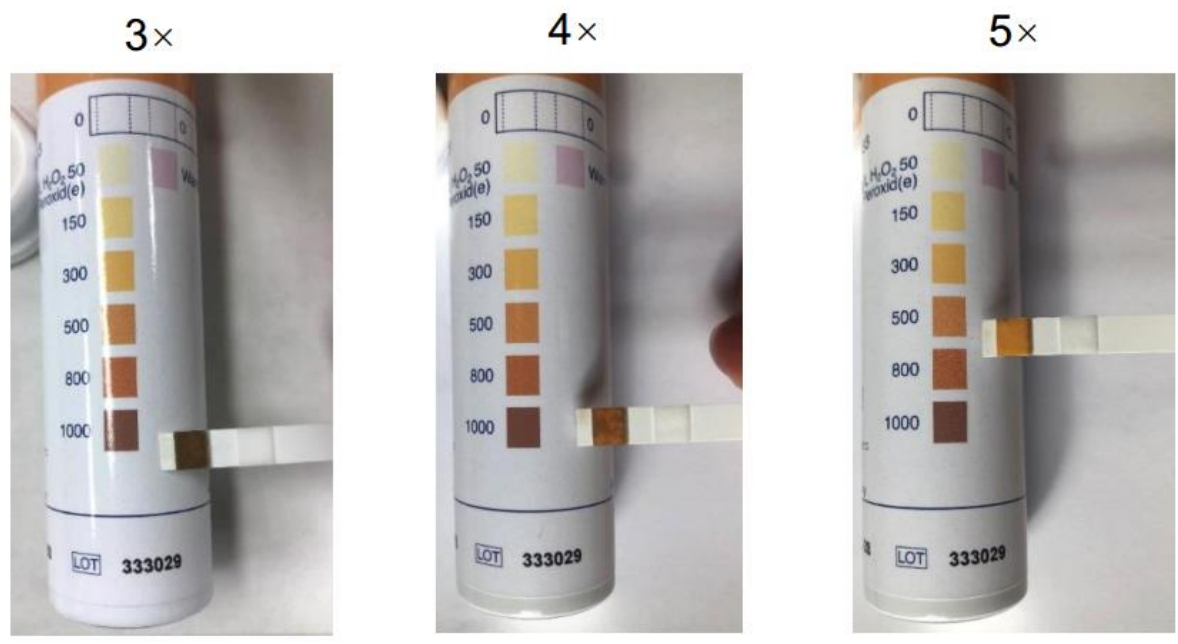

Figure S18. Photos of $\mathrm{H}_{2} \mathrm{O}_{2}$ test-strips measuring final electrolyte following an $11 \mathrm{~h}$ test in $\mathrm{H}$-cell with different dilutions. The acidic electrolyte $\left(0.10 \mathrm{M} \mathrm{HClO}_{4}\right)$ was buffered with $1.0 \mathrm{M} \mathrm{KOH}$ to a $\mathrm{pH}$ of $\sim 7$ to obviate any interference.
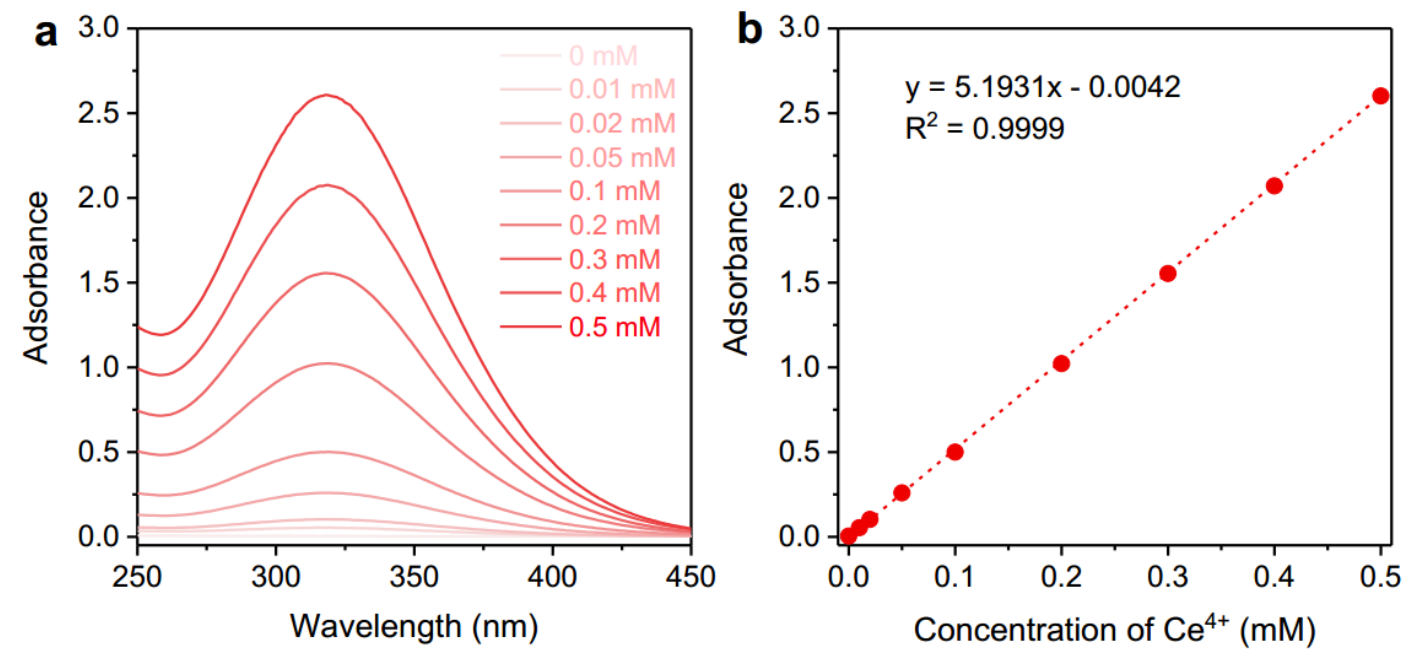

Figure S19. (a) UV-vis spectra of $\mathrm{Ce}^{4+}$ solution with various concentrations, and (b) corresponding standard curve. 


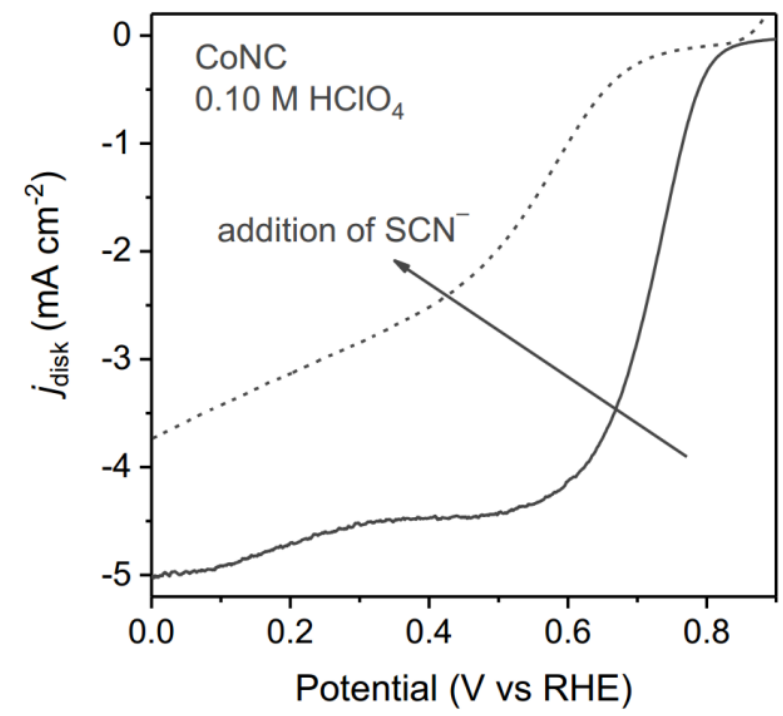

Figure S20. ORR LSV curves for CoNC before and following addition of $10 \mathrm{mM}$ KSCN in 0.10 $\mathrm{M} \mathrm{HClO}_{4}$.

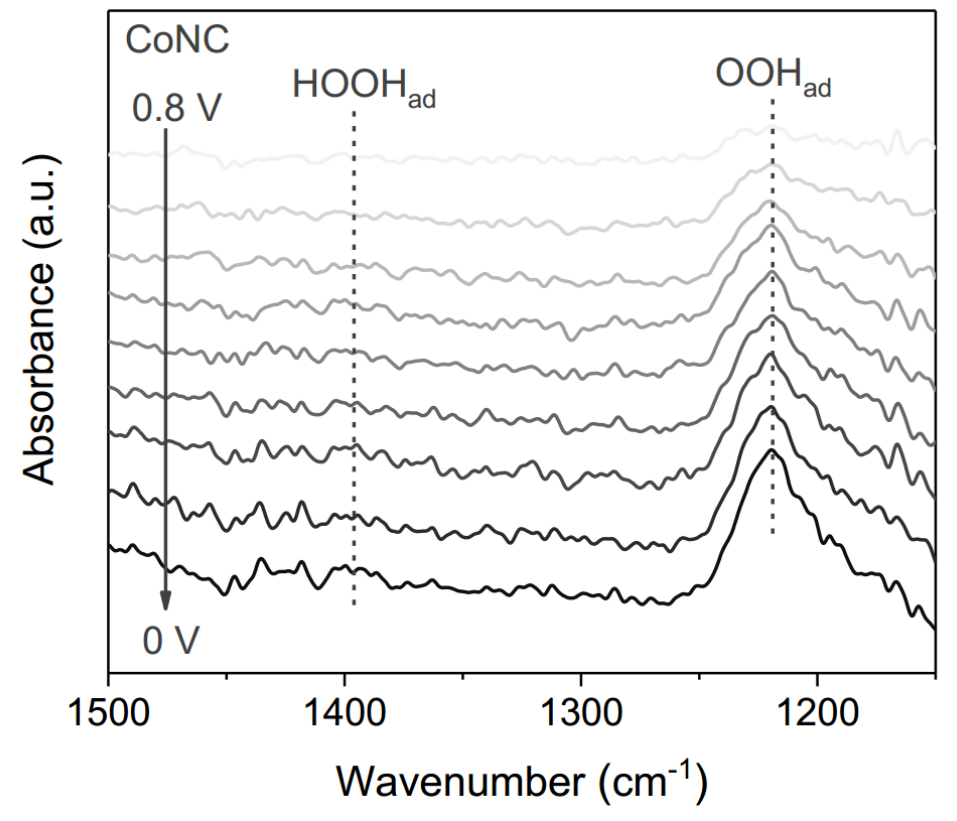

Figure S21. In situ ATR-SEIRAS spectra recorded on CoNC in $\mathrm{O}_{2}$-saturated $0.10 \mathrm{M} \mathrm{HClO}_{4}$ during constant potential steps from $0.8 \mathrm{~V}$ to $0 \mathrm{~V}$ vs RHE. 


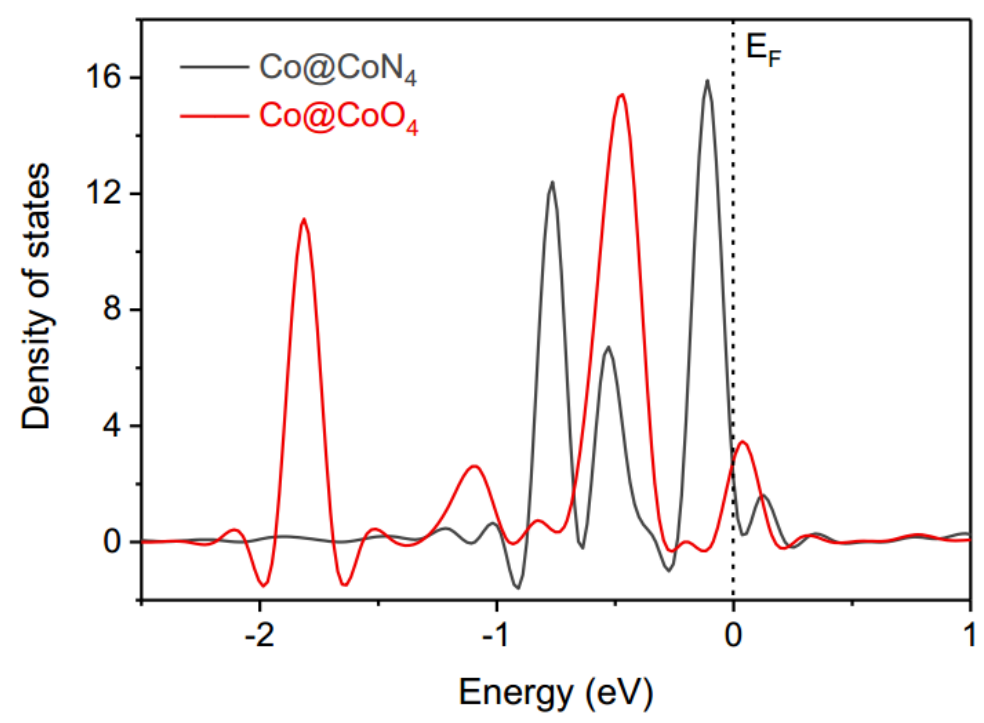

Figure S22. D-projected DOS of center Co atom in $\mathrm{CoN}_{4}$ and $\mathrm{CoO}_{4}$ moieties. $\mathrm{E}_{\mathrm{F}}$ is Fermi level.

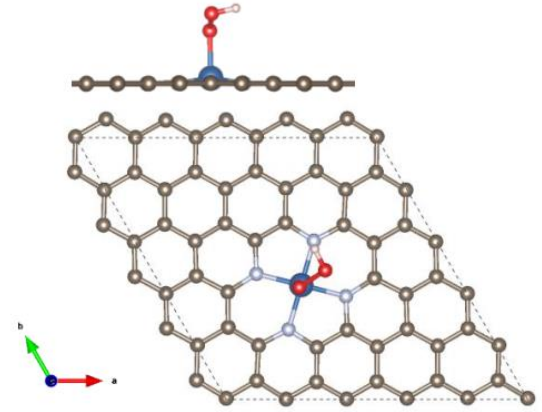

(1) *OOH@ $\mathrm{CoN}_{4}$

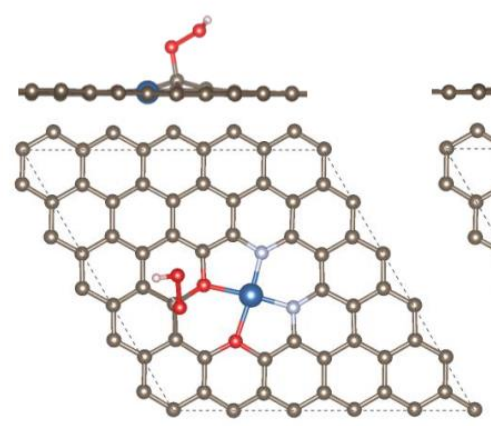

(3) * $\mathrm{OOH} @ \mathrm{CoN}_{2} \mathrm{O}_{2}$

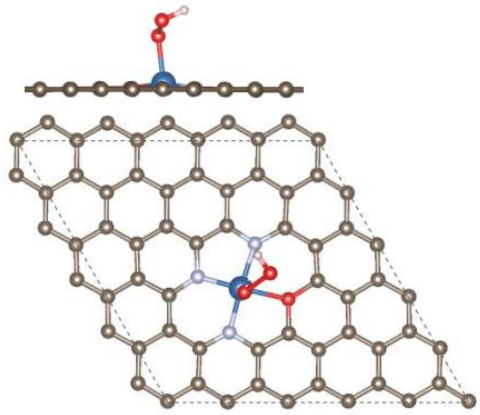

(2) * $\mathrm{OOH} @ \mathrm{CoN}_{3} \mathrm{O}$

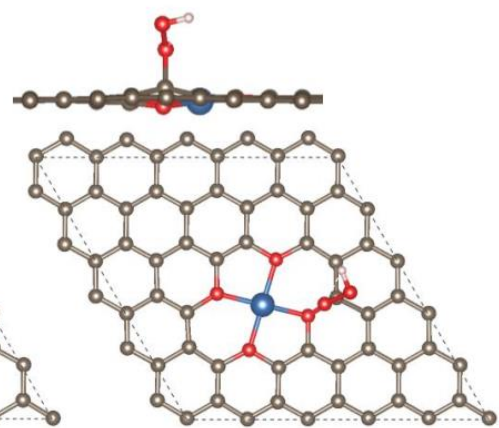

(5) * $\mathrm{OOH} @ \mathrm{CoO}_{4}$

Figure S23. Optimized geometry structures showing top view (plan) and side view (elevation) of $* \mathrm{OOH}$ adsorption on $\mathrm{CoN}_{4}, \mathrm{CoN}_{3} \mathrm{O}, \mathrm{CoN}_{2} \mathrm{O}_{2}, \mathrm{CoNO}_{3}$, and $\mathrm{CoO}_{4}$ moieties. 
a

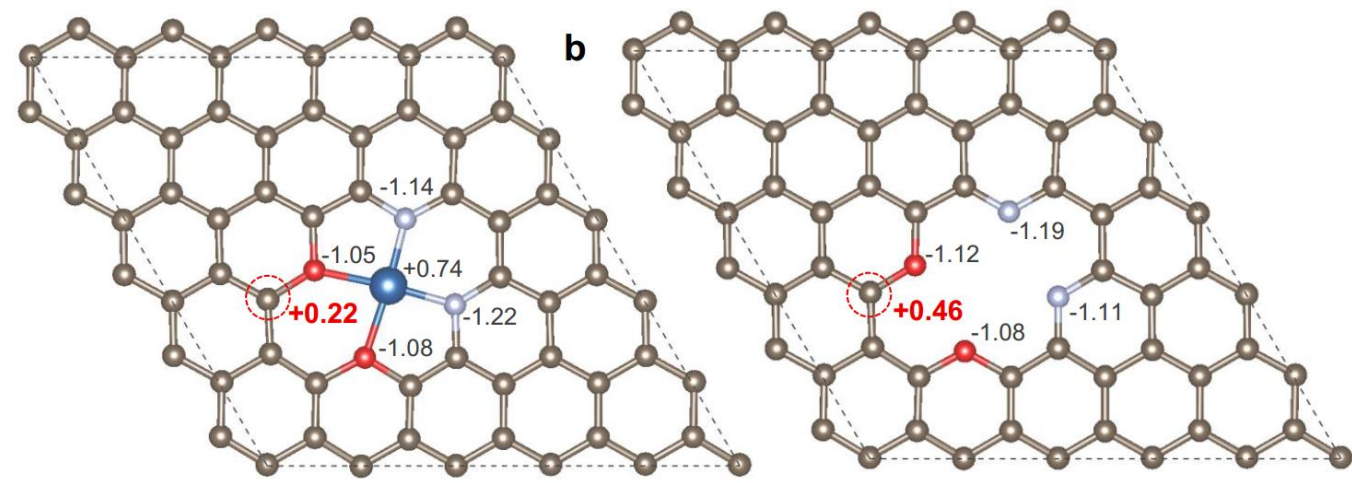

Figure S24. Bader charge distribution for $\mathrm{CoN}_{2} \mathrm{O}_{2}$ and $\mathrm{N}_{2} \mathrm{O}_{2}$ moieties showing $-0.24|\mathrm{e}|$ more electrons transferred from $\mathrm{Co}$ to $\mathrm{O}$-adjacent active site $\mathrm{C}$ atom through structural effect. The blackand red-color numbers are the net Bader charge of nearest atoms.
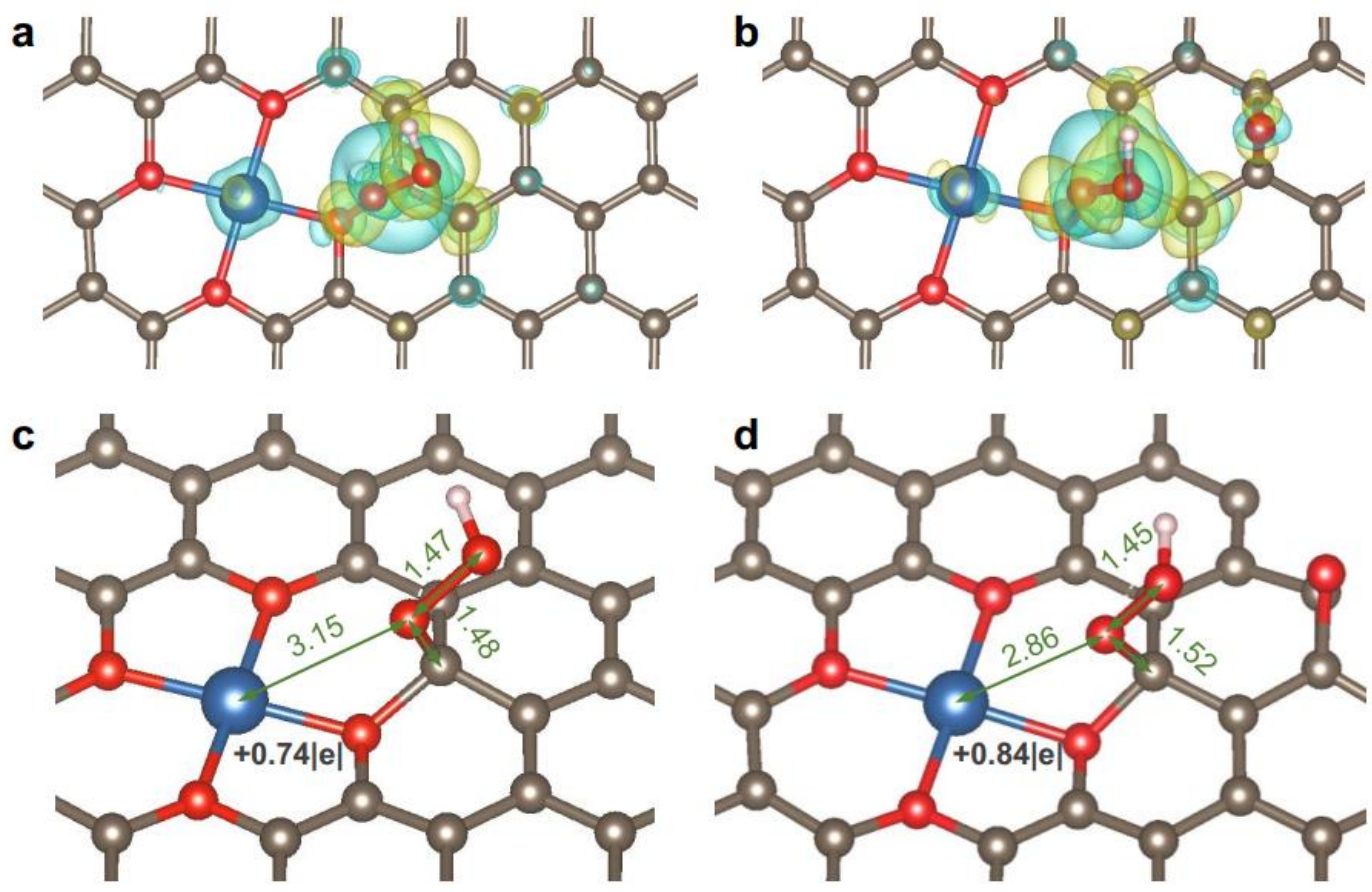

Figure S25. (a) Differential charge densities for $\mathrm{CoO}_{4}$ and $\mathrm{CoO}_{4}(\mathrm{O})$ following $* \mathrm{OOH}$ adsorption. Yellow- and cyan-color isosurfaces show, respectively, electron gain and loss. (c, d) Black-color numbers show net Bader charge of the center Co atoms. Green-color numbers show the distance between adjacent atoms of $\mathrm{Co}-\mathrm{O}, \mathrm{C}-\mathrm{O}$, and $\mathrm{O}-\mathrm{O}$. 


\section{Supplementary Tables}

Table S1. Free energy for $\mathrm{O}_{2}, \mathrm{H}_{2} \mathrm{O}_{2}, \mathrm{H}_{2}$ and $\mathrm{H}_{2} \mathrm{O}$ as computed traditionally. ${ }^{13}$

\begin{tabular}{ccccc}
\hline & $\begin{array}{c}\boldsymbol{E} \\
(\mathbf{e V})\end{array}$ & $\begin{array}{c}\boldsymbol{Z P E} \\
(\mathbf{e V})\end{array}$ & $\begin{array}{l}-\boldsymbol{T S} \\
(\mathbf{e V})\end{array}$ & $\begin{array}{c}\boldsymbol{G} \\
(\mathbf{e V})\end{array}$ \\
\hline $\mathrm{O}_{2}(\mathrm{~g})$ & -- & -- & -- & -9.958 \\
$\mathrm{H}_{2}(\mathrm{~g})$ & -6.752 & 0.27 & -0.41 & -6.892 \\
$\mathrm{H}_{2} \mathrm{O}(\mathrm{g})$ & -14.221 & 0.56 & -0.67 & -14.331 \\
$\mathrm{H}_{2} \mathrm{O}_{2}(\mathrm{~g})$ & -18.14 & 0.78 & -0.88 & -18.24 \\
\hline
\end{tabular}

Table S2. Summary of computed Bader charge, $\Delta G * \mathrm{OOH}$ and $U_{\mathrm{L}}$ for the 12 models.

\begin{tabular}{|c|c|c|c|c|}
\hline & \multicolumn{2}{|c|}{ Bader charge $(-|e|)$} & \multirow[t]{2}{*}{$\Delta G *$ оОН $(\mathrm{eV})$} & \multirow[t]{2}{*}{$U_{\mathbf{L}}(\mathbf{V})$} \\
\hline & $\mathrm{C}$ (active site) & $\mathrm{Co}$ & & \\
\hline $\mathrm{CoN}_{4}$ & -- & 8.13 & 3.90 & 1.02 \\
\hline $\mathrm{CoN}_{4}(\mathrm{O})$ & -- & -- & 4.36 & 0.56 \\
\hline $\mathrm{CoN}_{4}(2 \mathrm{O})$ & -- & -- & 4.43 & 0.49 \\
\hline $\mathrm{CoN}_{3} \mathrm{O}$ & -- & 8.23 & 4.28 & 0.64 \\
\hline $\mathrm{CoN}_{2} \mathrm{O}_{2}$ & 3.78 & 8.26 & 4.23 & 0.69 \\
\hline $\mathrm{CoN}_{2} \mathrm{O}_{2}(\mathrm{O})$ & 3.67 & 8.20 & 4.30 & 0.62 \\
\hline $\mathrm{CoN}_{2} \mathrm{O}_{2}(2 \mathrm{O})$ & 3.74 & 8.14 & 4.29 & 0.63 \\
\hline $\mathrm{N}_{2} \mathrm{O}_{2}$ & 3.54 & -- & 4.40 & 0.51 \\
\hline $\mathrm{CoNO}_{3}$ & 3.63 & 8.26 & 4.51 & 0.41 \\
\hline $\mathrm{CoO}_{4}$ & 3.79 & 8.22 & 4.35 & 0.57 \\
\hline $\mathrm{CoO}_{4}(\mathrm{O})$ & 3.56 & 8.28 & 4.21 & 0.71 \\
\hline $\mathrm{O}_{4}(\mathrm{O})$ & 3.48 & -- & 4.55 & 0.37 \\
\hline
\end{tabular}


Table S3. Co K-edge EXAFS curve-fitting parameters for Co SACs and reference samples. ${ }^{a}$

\begin{tabular}{|c|c|c|c|c|c|c|}
\hline Sample & Path & $N$ & $\begin{array}{c}R \\
(\AA) \\
(\AA)\end{array}$ & $\begin{array}{c}\sigma^{2} \\
\left(\times 10^{-3} \AA^{2}\right) \\
\end{array}$ & $\begin{array}{l}\Delta E_{0} \\
(\mathrm{eV})\end{array}$ & $\begin{array}{c}R \text {-factor } \\
(\%)\end{array}$ \\
\hline Co-foil ${ }^{b}$ & $\mathrm{Co}-\mathrm{Co}$ & 12 & 2.49 & 5.0 & 0.7 & 0.01 \\
\hline \multirow{2}{*}{$\mathrm{CoO}^{c}$} & $\mathrm{Co}-\mathrm{O}$ & 6 & 2.12 & 3.1 & \multirow{2}{*}{2.2} & \multirow{2}{*}{0.01} \\
\hline & $\mathrm{Co}-\mathrm{Co}$ & 12 & 2.97 & 6.0 & & \\
\hline \multirow{2}{*}{$\mathrm{CoO}^{d}$} & $\mathrm{Co}-\mathrm{O} 1$ & 4 & 1.94 & 3.7 & \multirow{2}{*}{0.8} & \multirow{2}{*}{0.01} \\
\hline & $\mathrm{Co}-\mathrm{O} 2$ & 12 & 3.36 & 4.6 & & \\
\hline $\mathrm{CoPc}^{d}$ & $\mathrm{Co}^{-} \mathrm{O}$ & 4 & 1.85 & 2.2 & 1.2 & 0.01 \\
\hline \multirow{2}{*}{$\mathrm{CoNOC}^{e}$} & $\mathrm{Co}^{-} \mathrm{O}$ & 2.3 & 2.01 & 9.0 & 10.6 & \multirow{2}{*}{0.07} \\
\hline & $\mathrm{Co}-\mathrm{N}$ & 1.9 & 1.89 & 8.0 & 2.1 & \\
\hline \multirow{2}{*}{$\mathrm{CoOC}^{e}$} & $\mathrm{Co}-\mathrm{O} 1$ & 2 & 1.90 & 6.8 & 10.8 & \multirow{2}{*}{0.07} \\
\hline & $\mathrm{Co}-\mathrm{O} 2$ & 2 & 2.06 & 3.0 & 13.2 & \\
\hline \multirow{2}{*}{$\mathrm{CoNC}^{e}$} & $\mathrm{Co}-\mathrm{N} 1$ & 2.2 & 1.85 & 8.1 & 2.9 & \multirow{2}{*}{0.07} \\
\hline & $\mathrm{Co}-\mathrm{N} 2$ & 2.6 & 2.04 & 8.8 & 9.6 & \\
\hline
\end{tabular}

${ }^{\mathrm{a}} N$, coordination number; $R$, distance between absorber and backscatter atoms; $\sigma^{2}$, Debye-Waller factor to account for both thermal and structural disorders; $\Delta E_{0}$, inner potential correction; $R$-factor (\%) indicates the goodness of the fit. Error bounds (accuracies) that characterize the structural parameters obtained by EXAFS spectroscopy were estimated as $N \pm 20 \% ; R \pm 1 \% ; \sigma^{2} \pm 20 \% ; \Delta E_{0}$ $\pm 20 \%$. $S_{0}^{2}$ was fixed to 1.0. Bold numbers indicate fixed coordination number $(N)$ according to the crystal structure. ${ }^{b}$ Fitting range: $2.0 \leq k\left(\AA^{-1}\right) \leq 12.5$ and $1.0 \leq R(\AA) \leq 3.0$. ${ }^{c}$ Fitting range: 2.0 $\leq k\left(\AA^{-1}\right) \leq 12.5$ and $1.0 \leq R(\AA) \leq 3.2 .{ }^{d}$ Fitting range: $2.0 \leq k\left(\AA^{-1}\right) \leq 10.0$ and $1.0 \leq R(\AA) \leq 3.0$. ${ }^{e}$ Fitting range: $2.0 \leq k\left(\AA^{-1}\right) \leq 10.0$ and $1.0 \leq R(\AA) \leq 2.5$. 
Table S4. Summary comparison of electrochemical $\mathrm{H}_{2} \mathrm{O}_{2}$ production via $2 \mathrm{e}^{-}$ORR in acid. $j_{0.1 \mathrm{v}}$ is disk current density at $0.1 \mathrm{~V}$ vs RHE. $j_{0.2} \mathrm{v}$ is disk current density at $0.2 \mathrm{~V}$ vs RHE. $j_{0.1} \mathrm{v}$ and $j_{0.2 \mathrm{~V}}$ were estimated from corresponding LSV curves obtained at $1600 \mathrm{rpm}$. All potentials shown are corrected based on RHE.

\begin{tabular}{|c|c|c|c|c|c|c|c|}
\hline Catalyst & Electrolyte & $\begin{array}{c}j 0.1 \mathrm{v} \\
\left(-\mathrm{mA} \mathbf{c m}^{-2}\right)\end{array}$ & $\begin{array}{c}j 0.2 \mathrm{~V} \\
\left(-\mathrm{mA} \mathrm{cm}^{-2}\right)\end{array}$ & $\begin{array}{c}\text { Selectivity } \\
(\% @ V)\end{array}$ & Stability & $\begin{array}{c}\text { Accumulation } \\
\left(\mathbf{m m o l} \mathrm{gcat}^{-1} \mathbf{h}^{-1} @ \mathbf{V}\right)\end{array}$ & Reference \\
\hline CoNOC & $0.10 \mathrm{M} \mathrm{HClO}_{4}$ & 2.8 & 2.5 & $\begin{array}{c}>95 \\
@(0.1-0.6)\end{array}$ & $11 \mathrm{~h}$ & $\begin{array}{l}590 @ 0.1 \text { V } \\
\text { (H-type cell) }\end{array}$ & This work \\
\hline $\mathrm{Pt}-\mathrm{Hg} / \mathrm{C}$ & $0.10 \mathrm{M} \mathrm{HClO}_{4}$ & 0.8 & 0.7 & $\begin{array}{c}\sim 90 \\
@(0.3-0.5)\end{array}$ & 8,000 cycles & N/A & 18 \\
\hline $\mathrm{Pt}-\mathrm{Hg} \mathrm{pc}$ & $0.10 \mathrm{M} \mathrm{HClO}_{4}$ & 3.6 & 3.3 & $\begin{array}{c}\sim 96 \\
@(0.2-0.4)\end{array}$ & N/A & N/A & 18 \\
\hline $\begin{array}{l}\mathrm{HE}-\mathrm{CoN} \\
@ \mathrm{CNTs}\end{array}$ & $0.10 \mathrm{M} \mathrm{HClO}_{4}$ & 3 & 2.8 & $\begin{array}{c}95-97.5 \\
@(0.3-0.6)\end{array}$ & $\begin{array}{c}12 \mathrm{~h} \\
@ 0.45 \mathrm{~V}\end{array}$ & $\begin{array}{c}8.6 \mathrm{~mol} \mathrm{~L}{ }^{-1} \mathrm{~g}_{\text {cat }}{ }^{-1} \mathrm{~h}^{-1} \\
@ 0.3 \mathrm{~V} \\
\text { (flow cell) }\end{array}$ & 19 \\
\hline $\mathrm{Co}_{1}-\mathrm{NG}(\mathrm{O})$ & $0.10 \mathrm{M} \mathrm{HClO}_{4}$ & NA & 1.8 & $\begin{array}{c}\sim 45 \\
@(0.2-0.7)\end{array}$ & $10 \mathrm{~h}$ & N/A & 20 \\
\hline $\mathrm{Co}_{1}-\mathrm{ZIF}(\mathrm{O})$ & $0.10 \mathrm{M} \mathrm{HClO}_{4}$ & NA & 2.5 & $\begin{array}{c}\sim 60 \\
@(0.2-0.7)\end{array}$ & NA & N/A & 20 \\
\hline Co-NC & $0.10 \mathrm{M} \mathrm{HClO}_{4}$ & 3 & 2.8 & $\begin{array}{c}\sim 90 \\
@(0.3-0.6)\end{array}$ & $10 \mathrm{~h}$ & $\begin{array}{c}275 @ 0.4 \text { V } \\
\text { (H-type cell) }\end{array}$ & 21 \\
\hline Co-N-C & $0.5 \mathrm{M} \mathrm{H}_{2} \mathrm{SO}_{4}$ & 3 & 2.9 & $\begin{array}{c}\sim 75 \\
@(0.1-0.3)\end{array}$ & N/A & N/A & 22 \\
\hline MNC-50 & $0.5 \mathrm{M} \mathrm{H}_{2} \mathrm{SO}_{4}$ & 2.5 & 2.3 & $\begin{array}{c}\sim 94 \\
@(0-0.4)\end{array}$ & N/A & N/A & 23 \\
\hline NF-Cs & $0.5 \mathrm{M} \mathrm{H}_{2} \mathrm{SO}_{4}$ & 3.9 & 3.7 & $\begin{array}{c}\sim 70 \\
@(0.1-0.3)\end{array}$ & $1,000 \mathrm{~min}$ & N/A & 24 \\
\hline NCMK3IL50 & $0.5 \mathrm{M} \mathrm{H}_{2} \mathrm{SO}_{4}$ & 1.4 & 0.75 & $\begin{array}{c}>95 \\
@(0.15-0.35)\end{array}$ & $6 \mathrm{~h}$ & $\begin{array}{l}\text { 159.9@0.1 V } \\
\text { (H-type cell) }\end{array}$ & 25 \\
\hline
\end{tabular}




\begin{tabular}{|c|c|c|c|c|c|c|c|}
\hline $\mathrm{CoS}_{2}$ & $0.05 \mathrm{M} \mathrm{H}_{2} \mathrm{SO}_{4}$ & 2 & 1.8 & $\begin{array}{c}80 \\
@(0.3-0.6)\end{array}$ & $60 \mathrm{~min}$ & $\begin{array}{l}24.5 @ 0.5 \mathrm{~V} \\
\text { (H-type cell) }\end{array}$ & 26 \\
\hline$\{001\}-\mathrm{Fe}_{2} \mathrm{O}_{3-\mathrm{x}}$ & $5 \mathrm{mM} \mathrm{H}_{2} \mathrm{SO}_{4}$ & 1.2 & 1 & $\begin{array}{c}\sim 90 \% \\
@(0.2-0.4)\end{array}$ & $1,666 \mathrm{~min}$ & N/A & 27 \\
\hline $\mathrm{h}-\mathrm{Pt}_{1}-\mathrm{CuS}_{\mathrm{x}}$ & $0.10 \mathrm{M} \mathrm{HClO}_{4}$ & 2.7 & 2.7 & $\begin{array}{c}\sim 93 \% \\
@(0.1-0.4)\end{array}$ & $10 \mathrm{~h}$ & $\begin{array}{l}546 @ 0.05 \mathrm{~V} \\
\left(0.5 \mathrm{M} \mathrm{HClO}_{4}, \mathrm{H}-\right. \\
\text { type cell })\end{array}$ & 28 \\
\hline PEI50CMK3 & $0.5 \mathrm{M} \mathrm{H}_{2} \mathrm{SO}_{4}$ & 1.25 & 0.7 & $\begin{array}{c}\sim 95 \% \\
@(0.1-0.4)\end{array}$ & $4 \mathrm{~h}$ & $\begin{array}{l}34.1 @ 0.2 \text { V } \\
\text { (H-type cell) }\end{array}$ & 29 \\
\hline$o-\mathrm{CoSe}_{2}$ & $0.05 \mathrm{M} \mathrm{H}_{2} \mathrm{SO}_{4}$ & 4.4 & $\begin{array}{c}4 \\
(2025 \mathrm{rpm})\end{array}$ & $\begin{array}{c}\sim 80 \% \\
@(0.5-0.6)\end{array}$ & $6 \mathrm{~h}$ & $\begin{array}{c}\text { 4.8-11.1@0.5 V } \\
\text { (H-type cell) }\end{array}$ & 30 \\
\hline FPC-800 & $0.05 \mathrm{M} \mathrm{H}_{2} \mathrm{SO}_{4}$ & 1.35 & 0.6 & $\begin{array}{c}\sim 85 \% \\
@(0-0.1)\end{array}$ & $3 \mathrm{~h}$ & $\begin{array}{l}\text { 112.6@0.2 V } \\
\text { (H-type cell) }\end{array}$ & 31 \\
\hline $\mathrm{N} / \mathrm{C}$ & $0.5 \mathrm{M} \mathrm{H}_{2} \mathrm{SO}_{4}$ & 3 & 2.7 & $\begin{array}{l}50-80 \% \\
@(0-0.6)\end{array}$ & N/A & N/A & 32 \\
\hline $\begin{array}{l}\mathrm{Mn}-\mathrm{O} / \mathrm{N} \\
@ \mathrm{NCs}-50\end{array}$ & $0.10 \mathrm{M} \mathrm{HClO}_{4}$ & 1 & 0.5 & $\begin{array}{l}75-80 \% \\
@(0-0.4)\end{array}$ & 6,000 cycles & $\begin{array}{c}20 \\
\text { (Single cell, } \\
\text { membrane electrode } \\
\text { assemblies) }\end{array}$ & 33 \\
\hline $\begin{array}{c}\mathrm{MoTe}_{2} \\
\text { nanoflakes }\end{array}$ & $0.5 \mathrm{M} \mathrm{H}_{2} \mathrm{SO}_{4}$ & 1.4 & 1 & $\begin{array}{l}90-95 \% \\
@(0-0.4)\end{array}$ & $12 \mathrm{~h}$ & N/A & 34 \\
\hline $\mathrm{Pt} / \mathrm{HSC}$ & $0.10 \mathrm{M} \mathrm{HClO}_{4}$ & 1.6 & $\begin{array}{c}1.4 \\
(900 \mathrm{rpm})\end{array}$ & $\begin{array}{c}\sim 95 \% \\
@(0.1-0.7)\end{array}$ & $2 \mathrm{~h}$ & $\begin{array}{c}48.75 @ 0 \mathrm{~V} \\
\text { (H-type cell, } 1 \mathrm{M} \\
\left.\mathrm{HClO}_{4}\right)\end{array}$ & 35 \\
\hline Pd/GNR & $0.10 \mathrm{M} \mathrm{HClO}_{4}$ & 2.2 & 1.8 & $\begin{array}{c}93 \% \\
@(0.2-0.5)\end{array}$ & N/A & N/A & 36 \\
\hline
\end{tabular}




\section{Supplementary References}

(1) Wang, X. Q.; Chen, Z.; Zhao, X. Y.; Yao, T.; Chen, W. X.; You, R.; Zhao, C. M.; Wu, G.; Wang, J.; Huang, W. X.; Yang, J. L.; Hong, X.; Wei, S. Q.; Wu, Y.; Li, Y. D., Regulation of Coordination Number over Single Co Sites: Triggering the Efficient Electroreduction of $\mathrm{CO}_{2}$. Angew. Chem. Int. Ed. 2018, 57 (7), 1944-1948.

(2) Koningsberger, D. C.; Prins, R., X-Ray Absorption: Principles, Applications, Techniques of EXAFS, SEXAFS, and XANES. John Wiley and Sons, New York, NY: 1988.

(3) Ravel, B.; Newville, M., Athena, Artemis, Hephaestus: Data Analysis for X-Ray Absorption Spectroscopy Using IFEFFIT. J. Synchrotron. Radiat. 2005, 12, 537-541.

(4) Li, L. Q.; Tang, C.; Zheng, Y.; Xia, B. Q.; Zhou, X. L.; Xu, H. L.; Qiao, S. Z., Tailoring Selectivity of Electrochemical Hydrogen Peroxide Generation by Tunable Pyrrolic-NitrogenCarbon. Adv. Energy Mater. 2020, 10 (21), 2000789.

(5) Miyake, H.; Ye, S.; Osawa, M., Electroless Deposition of Gold Thin Films on Silicon for Surface-Enhanced Infrared Spectroelectrochemistry. Electrochem. Commun. 2002, 4 (12), 973977.

(6) Mathew, K.; Sundararaman, R.; Letchworth-Weaver, K.; Arias, T. A.; Hennig, R. G., Implicit Solvation Model for Density-Functional Study of Nanocrystal Surfaces and Reaction Pathways. J. Chem. Phys. 2014, 140 (8), 084106.

(7) Kresse, G.; Furthmuller, J., Efficient Iterative Schemes for Ab Initio Total-Energy Calculations Using a Plane-Wave Basis Set. Phys. Rev. B 1996, 54 (16), 11169-11186.

(8) Perdew, J. P.; Burke, K.; Ernzerhof, M., Generalized Gradient Approximation Made Simple. Phys. Rev. Lett. 1996, 77 (18), 3865-3868.

(9) Kresse, G.; Joubert, D., From Ultrasoft Pseudopotentials to the Projector Augmented-Wave Method. Phys. Rev. B 1999, 59 (3), 1758-1775.

(10) Monkhorst, H. J.; Pack, J. D., Special Points for Brillouin-Zone Integrations. Phys. Rev. B 1976, 13 (12), 5188-5192.

(11) Norskov, J. K.; Rossmeisl, J.; Logadottir, A.; Lindqvist, L.; Kitchin, J. R.; Bligaard, T.; Jonsson, H., Origin of the Overpotential for Oxygen Reduction at a Fuel-Cell Cathode. J. Phys. Chem. B 2004, 108 (46), 17886-17892. 
(12) Nie, X. W.; Esopi, M. R.; Janik, M. J.; Asthagiri, A., Selectivity of $\mathrm{CO}_{2}$ Reduction on Copper Electrodes: The Role of the Kinetics of Elementary Steps. Angew. Chem. Int. Ed. 2013, 52 (9), 2459-2462.

(13) Jiao, Y.; Zheng, Y.; Jaroniec, M.; Qiao, S. Z., Origin of the Electrocatalytic Oxygen Reduction Activity of Graphene-Based Catalysts: A Roadmap to Achieve the Best Performance. J. Am. Chem. Soc. 2014, 136 (11), 4394-4403.

(14) Henkelman, G.; Jonsson, H., Improved Tangent Estimate in the Nudged Elastic Band Method for Finding Minimum Energy Paths and Saddle Points. J. Chem. Phys. 2000, 113 (22), 9978-9985. (15) Sheng, Y. W.; Abreu, I. A.; Cabelli, D. E.; Maroney, M. J.; Miller, A. F.; Teixeira, M.; Valentine, J. S., Superoxide Dismutases and Superoxide Reductases. Chem. Rev. 2014, 114 (7), 3854-3918.

(16) Buss, J. A.; VanderVelde, D. G.; Agapie, T., Lewis Acid Enhancement of Proton Induced $\mathrm{CO}_{2}$ Cleavage: Bond Weakening and Ligand Residence Time Effects. J. Am. Chem. Soc. 2018, 140 (32), 10121-10125.

(17) Noffke, B. W.; Li, Q. Q.; Raghavachari, K.; Li, L. S. A Model for the pH-Dependent Selectivity of the Oxygen Reduction Reaction Electrocatalyzed by N-Doped Graphitic Carbon. $J$. Am. Chem. Soc. 2016, 138 (42), 13923-13929.

(18) Siahrostami, S.; Verdaguer-Casadevall, A.; Karamad, M.; Deiana, D.; Malacrida, P.; Wickman, B.; Escudero-Escribano, M.; Paoli, E. A.; Frydendal, R.; Hansen, T. W.; Chorkendorff, I.; Stephens, I. E. L.; Rossmeisl, J., Enabling Direct $\mathrm{H}_{2} \mathrm{O}_{2}$ Production through Rational Electrocatalyst Design. Nat. Mater. 2013, 12 (12), 1137-1143.

(19) Zhang, Q. R.; Tan, X.; Bedford, N. M.; Han, Z. J.; Thomsen, L.; Smith, S.; Amal, R.; Lu, X. Y., Direct Insights into the Role of Epoxy Groups on Cobalt Sites for Acidic $\mathrm{H}_{2} \mathrm{O}_{2}$ Production. Nat. Commun. 2020, 11 (1), 4181.

(20) Jung, E.; Shin, H.; Lee, B. H.; Efremov, V.; Lee, S.; Lee, H. S.; Kim, J.; Hooch Antink, W.; Park, S.; Lee, K. S.; Cho, S. P.; Yoo, J. S.; Sung, Y. E.; Hyeon, T., Atomic-Level Tuning of CoN-C Catalyst for High-Performance Electrochemical $\mathrm{H}_{2} \mathrm{O}_{2}$ Production. Nat. Mater. 2020, 19 (4), 436-442.

(21) Gao, J. J.; Yang, H. B.; Huang, X.; Hung, S. F.; Cai, W. Z.; Jia, C. M.; Miao, S.; Chen, H. M.; Yang, X. F.; Huang, Y. Q.; Zhang, T.; Liu, B., Enabling Direct $\mathrm{H}_{2} \mathrm{O}_{2}$ Production in Acidic Media through Rational Design of Transition Metal Single Atom Catalyst. Chem 2020, 6 (3), 658-674. 
(22) Sun, Y. Y.; Silvioli, L.; Sahraie, N. R.; Ju, W.; Li, J. K.; Zitolo, A.; Li, S.; Bagger, A.; Arnarson, L.; Wang, X. L.; Moeller, T.; Bernsmeier, D.; Rossmeisl, J.; Jaouen, F.; Strasser, P., Activity-Selectivity Trends in the Electrochemical Production of Hydrogen Peroxide over SingleSite Metal-Nitrogen-Carbon Catalysts. J. Am. Chem. Soc. 2019, 141 (31), 12372-12381.

(23) Park, J.; Nabae, Y.; Hayakawa, T.; Kakimoto, M. A., Highly Selective Two-Electron Oxygen Reduction Catalyzed by Mesoporous Nitrogen-Doped Carbon. ACS Catal. 2014, 4 (10), 37493754.

(24) Jia, N.; Yang, T.; Shi, S. F.; Chen, X. B.; An, Z. W.; Chen, Y.; Yin, S. W.; Chen, P., N, FCodoped Carbon Nanocages: An Efficient Electrocatalyst for Hydrogen Peroxide Electroproduction in Alkaline and Acidic Solutions. ACS Sustainable Chem. Eng. 2020, 8 (7), 2883-2891.

(25) Sun, Y. Y.; Sinev, I.; Ju, W.; Bergmann, A.; Dresp, S.; Kuhl, S.; Spori, C.; Schmies, H.; Wang, H.; Bernsmeier, D.; Paul, B.; Schmack, R.; Kraehnert, R.; Roldan Cuenya, B.; Strasser, P., Efficient Electrochemical Hydrogen Peroxide Production from Molecular Oxygen on NitrogenDoped Mesoporous Carbon Catalysts. ACS Catal. 2018, 8 (4), 2844-2856.

(26) Sheng, H. Y.; Hermes, E. D.; Yang, X. H.; Ying, D. W.; Janes, A. N.; Li, W. J.; Schmidt, J. R.; Jin, S., Electrocatalytic Production of $\mathrm{H}_{2} \mathrm{O}_{2}$ by Selective Oxygen Reduction Using EarthAbundant Cobalt Pyrite $\left(\mathrm{CoS}_{2}\right)$. ACS Catal. 2019, 9 (9), 8433-8442.

(27) Gao, R. J.; Pan, L.; Li, Z. W.; Shi, C. X.; Yao, Y. D.; Zhang, X. W.; Zou, J. J., Engineering Facets and Oxygen Vacancies over Hematite Single Crystal for Intensified Electrocatalytic $\mathrm{H}_{2} \mathrm{O}_{2}$ Production. Adv. Funct. Mater. 2020, 30 (24), 1910539.

(28) Shen, R. G.; Chen, W. X.; Peng, Q.; Lu, S. Q.; Zheng, L. R.; Cao, X.; Wang, Y.; Zhu, W.; Zhang, J. T.; Zhuang, Z. B.; Chen, C.; Wang, D. G.; Li, Y. D., High-Concentration Single Atomic Pt Sites on Hollow $\mathrm{CuS}_{x}$ for Selective $\mathrm{O}_{2}$ Reduction to $\mathrm{H}_{2} \mathrm{O}_{2}$ in Acid Solution. Chem 2019, 5 (8), 2099-2110.

(29) Sun, Y. Y.; Li, S.; Jovanov, Z. P.; Bernsmeier, D.; Wang, H.; Paul, B.; Wang, X. L.; Kuhl, S.; Strasser, P., Structure, Activity, and Faradaic Efficiency of Nitrogen-Doped Porous Carbon Catalysts for Direct Electrochemical Hydrogen Peroxide Production. ChemSusChem 2018, 11 (19), $3388-3395$. 
(30) Sheng, H. Y.; Janes, A. N.; Ross, R. D.; Kaiman, D.; Huang, J. Z.; Song, B.; Schmidt, J. R.; Jin, S., Stable and Selective Electrosynthesis of Hydrogen Peroxide and the Electro-Fenton Process on $\mathrm{CoSe}_{2}$ Polymorph Catalysts. Energy Environ. Sci. 2020, 13 (11), 4189-4203.

(31) Zhao, K.; Su, Y.; Quan, X.; Liu, Y. M.; Chen, S.; Yu, H. T., Enhanced $\mathrm{H}_{2} \mathrm{O}_{2}$ Production by Selective Electrochemical Reduction of $\mathrm{O}_{2}$ on Fluorine-Doped Hierarchically Porous Carbon. $J$. Catal. 2018, 357, 118-126.

(32) Wu, Y.; Muthukrishnan, A.; Nagata, S.; Nabae, Y., Kinetic Understanding of the Reduction of Oxygen to Hydrogen Peroxide over an N-Doped Carbon Electrocatalyst. J. Phys. Chem. C 2019, $123(7), 4590-4596$.

(33) Byeon, A.; Cho, J.; Kim, J. G. M.; Chae, K. H.; Park, H. Y.; Hong, S. W.; Ham, H. C.; Lee, S. W.; Yoon, K. R.; Kim, J. Y., High-Yield Electrochemical Hydrogen Peroxide Production from an Enhanced Two-Electron Oxygen Reduction Pathway by Mesoporous Nitrogen-Doped Carbon and Manganese Hybrid Electrocatalysts. Nanoscale Horiz. 2020, 5 (5), 832-838.

(34) Zhao, X.; Wang, Y.; Da, Y. L.; Wang, X. X.; Wang, T. T.; Xu, M. Q.; He, X. Y.; Zhou, W.; Li, Y. F.; Coleman, J. N.; Li, Y. G., Selective Electrochemical Production of Hydrogen Peroxide at Zigzag Edges of Exfoliated Molybdenum Telluride Nanoflakes. Natl. Sci. Rev. 2020, 7 (8), $1360-1366$.

(35) Choi, C. H.; Kim, M.; Kwon, H. C.; Cho, S. J.; Yun, S.; Kim, H. T.; Mayrhofer, K. J. J.; Kim, H.; Choi, M., Tuning Selectivity of Electrochemical Reactions by Atomically Dispersed Platinum Catalyst. Nat. Commun. 2016, 7, 10922.

(36) Fortunato, G. V.; Pizzutilo, E.; Mingers, A. M.; Kasian, O.; Chereyko, S.; Cardoso, E. S. F.; Mayrhofer, K. J. J.; Maia, G.; Ledendecker, M., Impact of Palladium Loading and Interparticle Distance on the Selectivity for the Oxygen Reduction Reaction toward Hydrogen Peroxide. J. Phys. Chem. C 2018, 122 (28), 15878-15885. 